\title{
Groundwater quality assessment using water quality index (WQI) under GIS framework
}

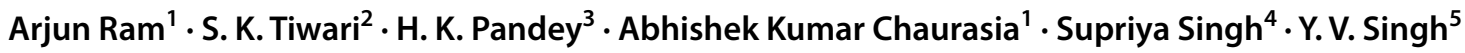

Received: 27 May 2020 / Accepted: 25 January 2021 / Published online: 12 February 2021

(c) The Author(s) 2021

\begin{abstract}
Groundwater is an important source for drinking water supply in hard rock terrain of Bundelkhand massif particularly in District Mahoba, Uttar Pradesh, India. An attempt has been made in this work to understand the suitability of groundwater for human consumption. The parameters like $\mathrm{pH}$, electrical conductivity, total dissolved solids, alkalinity, total hardness, calcium, magnesium, sodium, potassium, bicarbonate, sulfate, chloride, fluoride, nitrate, copper, manganese, silver, zinc, iron and nickel were analysed to estimate the groundwater quality. The water quality index (WQI) has been applied to categorize the water quality viz: excellent, good, poor, etc. which is quite useful to infer the quality of water to the people and policy makers in the concerned area. The WQI in the study area ranges from 4.75 to 115.93 . The overall WQI in the study area indicates that the groundwater is safe and potable except few localized pockets in Charkhari and Jaitpur Blocks. The Hill-Piper Trilinear diagram reveals that the groundwater of the study area falls under $\mathrm{Na}^{+}-\mathrm{Cl}^{-}$, mixed $\mathrm{Ca}^{2+}-\mathrm{Mg}^{2+}-\mathrm{Cl}^{-}$and $\mathrm{Ca}^{2+}-\mathrm{HCO}_{3}^{-}$ types. The granite-gneiss contains orthoclase feldspar and biotite minerals which after weathering yields bicarbonate and chloride rich groundwater. The correlation matrix has been created and analysed to observe their significant impetus on the assessment of groundwater quality. The current study suggests that the groundwater of the area under deteriorated water quality needs treatment before consumption and also to be protected from the perils of geogenic/anthropogenic contamination.
\end{abstract}

Keywords Groundwater · Hydrochemistry · WQI · GIS · Piper diagram · Bundelkhand massif

\section{Introduction}

H. K. Pandey

hkp@mnnit.ac.in

Arjun Ram

arjunram125@gmail.com

S. K. Tiwari

sktiwari.bhu@gmail.com

1 Department of Geology, Institute of Science, CAS, Banaras Hindu University, Varanasi 221005, India

2 UGC-HRDC, Banaras Hindu University, Varanasi 221005, India

3 Department of Civil Engineering, Motilal Nehru National Institute of Technology Allahabad, Prayagraj 211004, UP, India

4 Central Groundwater Board, Lucknow 226021, UP, India

5 Department of Soil Science \& Agricultural Chemistry, Banaras Hindu University, Varanasi 221005, India
In India, there has been a tremendous increase in the demand for groundwater due to rapid growth of population, accelerated pace of industrialization and urbanization (Yisa and Jimoh 2010). The availability and quality of groundwater are badly affected at an alarming rate due to anthropogenic activities viz. overexploitation and improper waste disposal (industrial, domestic and agricultural) to groundwater reservoirs (Panda and Sinha 1991; Kavitha et al. 2019a, 2019b). Consequently, human health is seriously threatened by the prevailing agricultural practices particularly in relation to excessive application of fertilizers; unsanitary conditions and disposal of sewage into groundwater (Panigrahi et al. 2012). The groundwater quality also varies with depth of water, seasonal changes, leached dissolved salts and subsurface environment (Gebrehiwot et al. 2011). According to the World Health Organization (WHO 2017), about 80\% of all the diseases in human beings are water-borne. Once the groundwater is contaminated, it is difficult to ensure its restoration and proper quality by preventing the pollutants 
from the source. It, therefore, becomes imperative to monitor the quality of groundwater regularly, and to device ways and means to protect it from contamination. The quality of groundwater is deciphered using various physical, chemical and biological characteristics of water (Diersing and Nancy 2009; Panneerselvam et al. 2020a). It is a measure of health and hygiene of groundwater concerning the need and purpose of human consumption (Johnson et al. 1997; Panneerselvam et al. 2020b).

In recent years, the assessment and monitoring of groundwater quality on a regular basis is being carried out using Geographic Information System (GIS) technique added with the IDW interpolation method and has proved itself as a powerful tool for evaluating and analysing spatial information of water resources (Aravindan et al. 2010; Shankar et al. 2010, 2011a, b; Venkateswaran et al. 2012; Selvam et al. 2013b; Magesh and Elango 2019; Balamurugan et al. 2020b; Soujanya Kamble et al. 2020). It is an economically feasible and time-efficient technique for transforming huge data sets to generate various spatial distribution maps and projections revealing trends, associations and sources of contaminants/pollutants. In this work, GIS technique has been used for spatial evaluation of various groundwater quality parameters.

In this study, the physicochemical properties of fortythree groundwater samples collected from wells and hand pumps were determined and compared with international standards of WHO for drinking and domestic uses based on Water Quality Index (WQI). The WQI was first developed by Horton (1965) based on weighted arithmetical calculation. A number of researchers (Brown et al. 1972; GEMS UNEP 2007; Kavitha and Elangovan 2010; Alobaidy et al. 2010; Shankar and Kawo 2019; Bawoke and Anteneh 2020 developed various WQI models based on weighing and rating of different water quality parameters which is derived by the weighted arithmetic method. The WQI is a dimensionless number with values ranking between 0 and 100 . The WQI is a unique digital rating expression that expresses overall water quality status viz. excellent, good, poor, etc. at a certain space and time based on various water quality parameters. Thus, the WQI is being used as an important tool to compare the quality of groundwater and their management (Jagadeeswari and Ramesh 2012) in a particular region; and is helpful for selecting appropriate economically feasible treatment process to cope up with the concerned quality issues. It depicts the composite impact of different water quality parameters and communicates water quality information to the public and legislative policy-makers to shape strong policy and implement the water quality programs (Kalavathy et al. 2011) by the government.

Mineral intractions strongly influence groundwater hydrochemistry in aquifers and disintegration of minerals from various source rocks (Cerar and Urbanc 2013; Modibo
Sidibé et al. 2019). Hydrochemistry of the analysed samples indicates that the mean abundance of major cations is present in order of $\mathrm{Na}^{++}>\mathrm{Ca}^{2+}>\mathrm{Mg}^{2+}>\mathrm{K}^{+}$while major anions in order of $\mathrm{HCO}_{3}^{-}>\mathrm{NO}_{3}^{-}>\mathrm{Cl}^{-}>\mathrm{SO}_{4}^{2-}>\mathrm{F}^{-}$. The study shows that the sodium is dominant alkali while calcium and magnesium are the dominant alkaline earth metal leached in the aquafer due to rock water interaction affecting the quality of groundwater. Sodium in aquafer is derived from the weathering of halite and silicate minerals such as feldspar (Khan et al. 2014; Mostafa et al. 2017). The critical evaluation of Hill-Piper Trilinear diagram reflects $\mathrm{Na}^{+}-\mathrm{Cl}^{-}$, mixed $\mathrm{Ca}^{2+}-\mathrm{Mg}^{2+}-\mathrm{Cl}^{-}, \mathrm{Ca}^{2+}-\mathrm{HCO}_{3}^{-}$, mixed $\mathrm{Ca}^{2+}-\mathrm{Na}^{+}-\mathrm{HCO}_{3}^{-}$, $\mathrm{Na}^{+}-\mathrm{HCO}_{3}^{-}$and $\mathrm{Ca}^{2+}-\mathrm{Cl}^{-}$type hydro-chemical facies in decreasing order of dominance. The Hydro-chemical characterization of groundwater reveals that the nature of aquifer is controlled by type of water, source and level of contamination (Aghazadeh et al. 2017; Brhane 2018). Hence, in order to keep the health of any aquaculture system, particularly an aquifer system at an optimal level, certain water quality indicators or parameters must be regularly monitored and controlled. Therefore, the objective of the study is to calculate the WQI of groundwater in order to assess its suitability for human consumption using the GIS interpolation technique and statistical approach in the study area.

\section{Study area}

Mahoba district is the south-western district of Uttar Pradesh which is adjacent to the state of Madhya Pradesh in south and Hamirpur (UP) in the north. The study area falls under the survey of India (SOI) toposheets no. 540 and $63 \mathrm{C}$ lies between latitude $\mathrm{N} 25^{\circ} 01^{\prime} 30^{\prime \prime}$ to N25 $39^{\prime} 40^{\prime \prime}$ and longitude $\mathrm{E} 79^{\circ} 15^{\prime} 00^{\prime \prime}$ to $\mathrm{E} 80^{\circ} 10^{\prime} 30^{\prime \prime}$ and covers an area of approximately $2933.59 \mathrm{~km}^{2}$. River Dhasan separates the district Mahoba from Jhansi in the west. A certainpart of Jhansi and Banda district has been merged in newly constructed Mahoba district in 1995 (bifurcated from Hamirpur). Mahoba district consists of three tehsils Kulpahar, Charkhari, Mahoba and four blocks Panwari, Jaitpur, Charkhari, Kabrai (Fig. 1a). Kabrai is the biggest block fromaerial coverage as well as population point of view. Jaitpur is the smallest block from aerial coverage and Charkhari from population point of view. The study area experiences a typical subtropical climate punctuated by long and intense summer, with distinct seasons. The area receives an average annual precipitation of $864 \mathrm{~mm}$ mainly from the south-west monsoon. The temperature of the coldest month (January) is $8.3^{\circ} \mathrm{C}$ while the temperature of the hottest month (May) shoots upto $47.5^{\circ} \mathrm{C}$. The entire area under investigation is characterised by highly jointed/fractured Bundelkhand granite (Archean age) with thin soil cover. Physiographically, the area is characterised by Bundelkhand massif terrain and is 


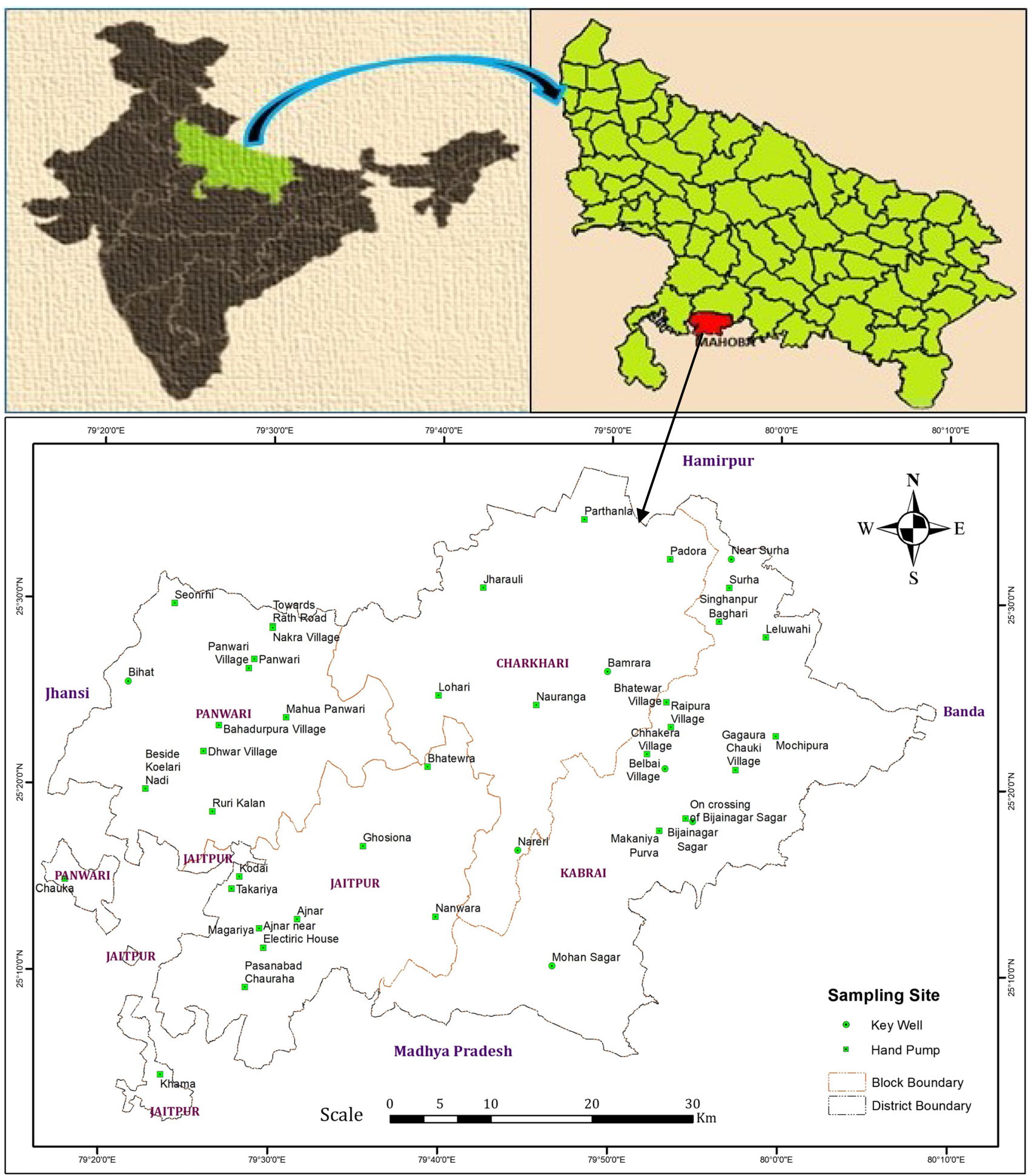

a Study Area Map depecting the sampling sites

Fig. 1 a Study area map depicting the sampling sites. b Geological map of study area

marked by the occurrence of solitary or clustered hillocks and intervening low relief with undulating plains. Two major physiographic units are: (1) Southern part having high relief with hillocks- This is south of $20^{\circ} 25^{\prime} \mathrm{N}$ latitude \& maximum altitude is 340 mamsl, reserved forest. Granitoids and intervening pegmatitic veins and numbers of quartz veins 


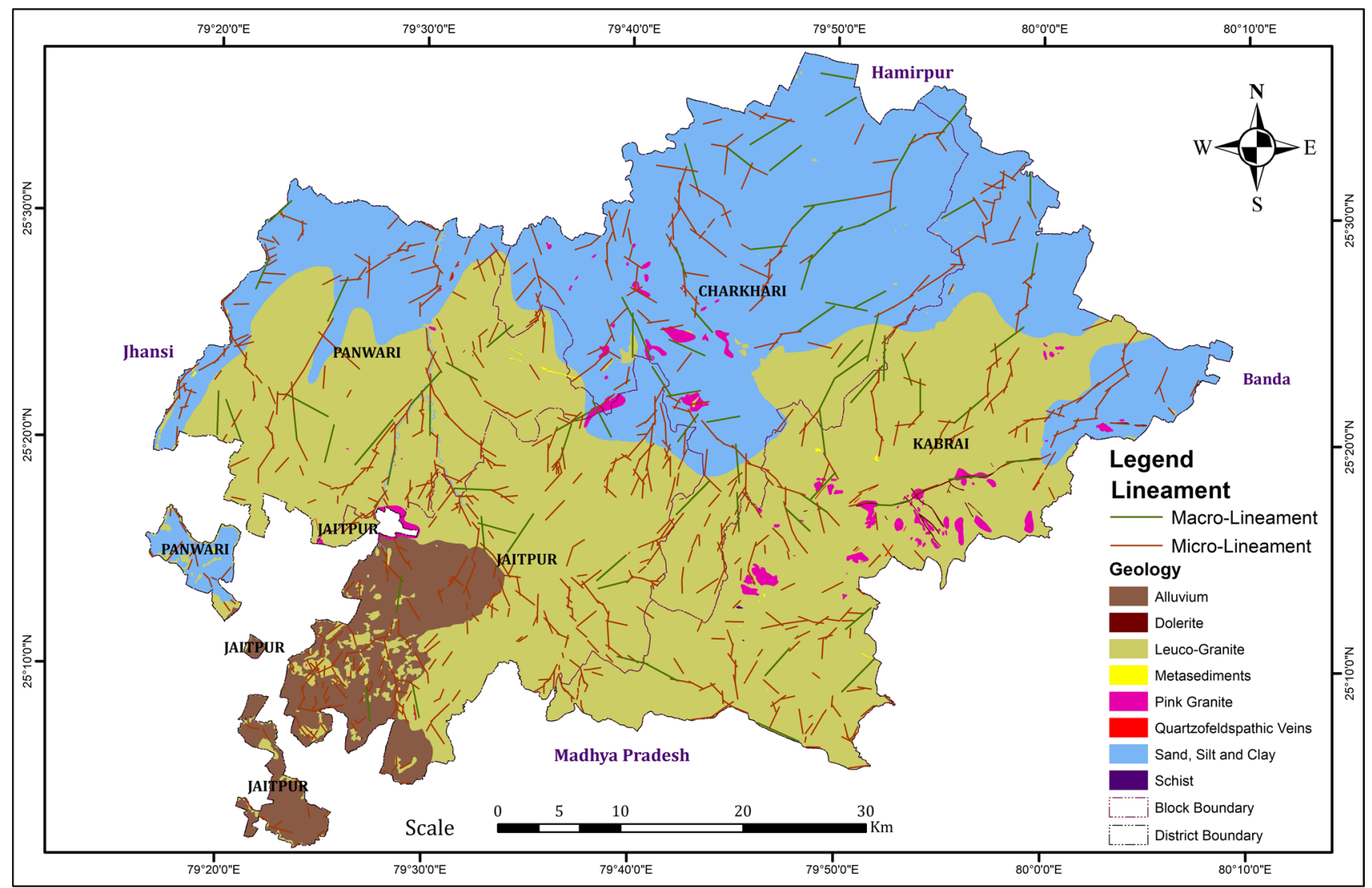

b Geological Map of Study area

Fig. 1 (continued)

are observed. (2) Northern part relatively low relief with lower hillocks- In between $25^{\circ} 25^{\prime} \mathrm{N}$ and $25^{\circ} 39^{\prime} \mathrm{N}$ latitude and maximum altitude is 310 mamsl. The area in and around Panwari is mainly covered with thick alluvium, and hard rock is encountered only below $35 \mathrm{mbgl}$, coverage with seasonal forest. Pedi plain, pediment inselberg and buried pediplains are present.

\section{Geological and hydrogeological set-up}

The granite, particularly leucogranite, older and younger alluvium consisting of clay, silt, sand and gravel mainly comprises the study area. The geological set-up of the study area indicates that the most dominant lithology is leucogranite covering mainly central and eastern part while recent alluvium covers the northern part (Fig. 1b). At places, few patches of pink granite have also been recorded which appears enclosed in leucogranite or adjacent to its outcrop. The occurrence of groundwater is highly uncertain and unpredictable in this hilly and rugged terrain as it does not allow percolation and storages underground. The presence of porosity depends on the intensity of weathering and rock fracture which is responsible for groundwater occurrence, its quantity and flow mostly in permeable zones of weathered rock formations and under secondary porosity in the deep fractured zone. Groundwater recharge in the study area is triggered by the depth of overburden $7 \mathrm{~m}$ (Jaitpur-Kulpahar area) to $35 \mathrm{~m}$ (parts of Mahoba Tahsil and Charkhari block) as well as the intensity of weathering.

\section{Materials and methods}

The groundwater samples were collected during pre-monsoon (June 2016) period from the study area according to standard procedures of the American Public Health Association (APHA, 2017). The sampling locations were marked with the help of global positioning system (GPS) as shown in the Fig. 1a. Samples were collected from the location through hand pump (depth: approx. $40 \mathrm{~m}$ ) and dug wells (depth: 8-30 m) as shown in Fig. 2a-t. The collecting bottles (High-Density Polythene, HDPE) of one-litre capacity each were sterilized under the aseptic condition to avoid 


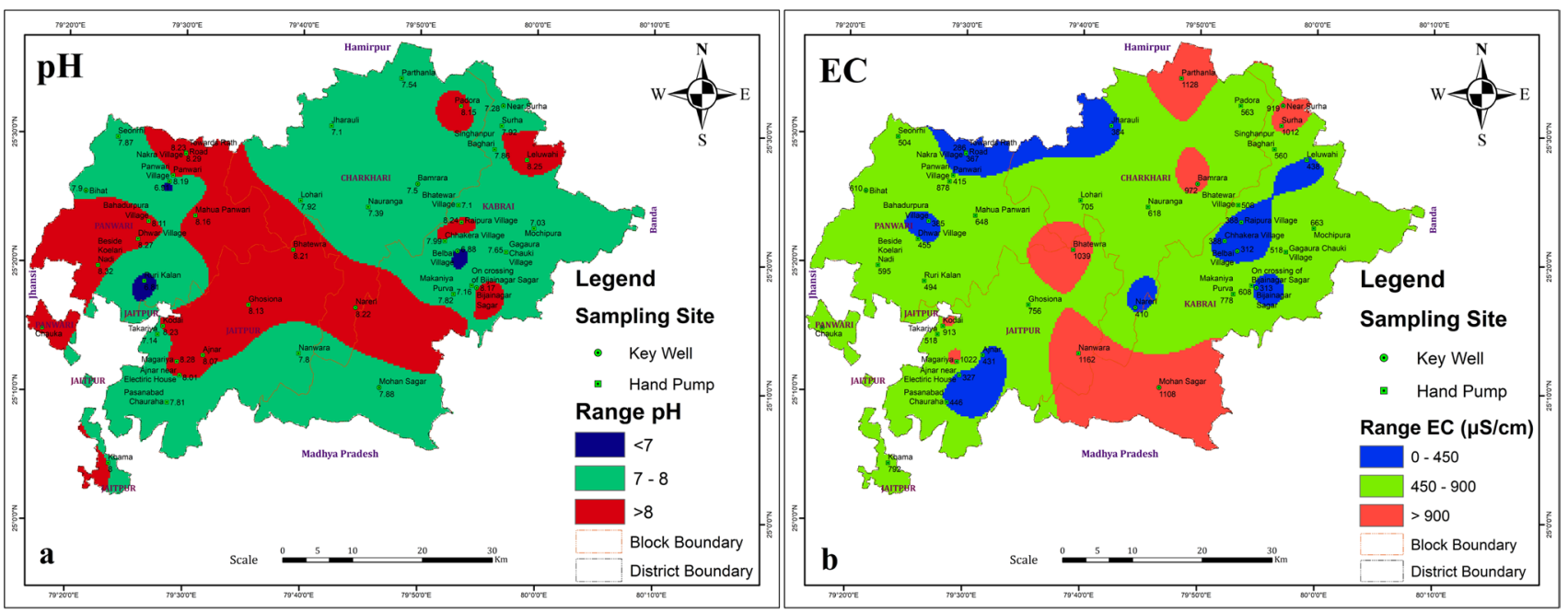

(a-b) spatial distribution map of $\mathrm{pH}$ and $\mathrm{EC}$
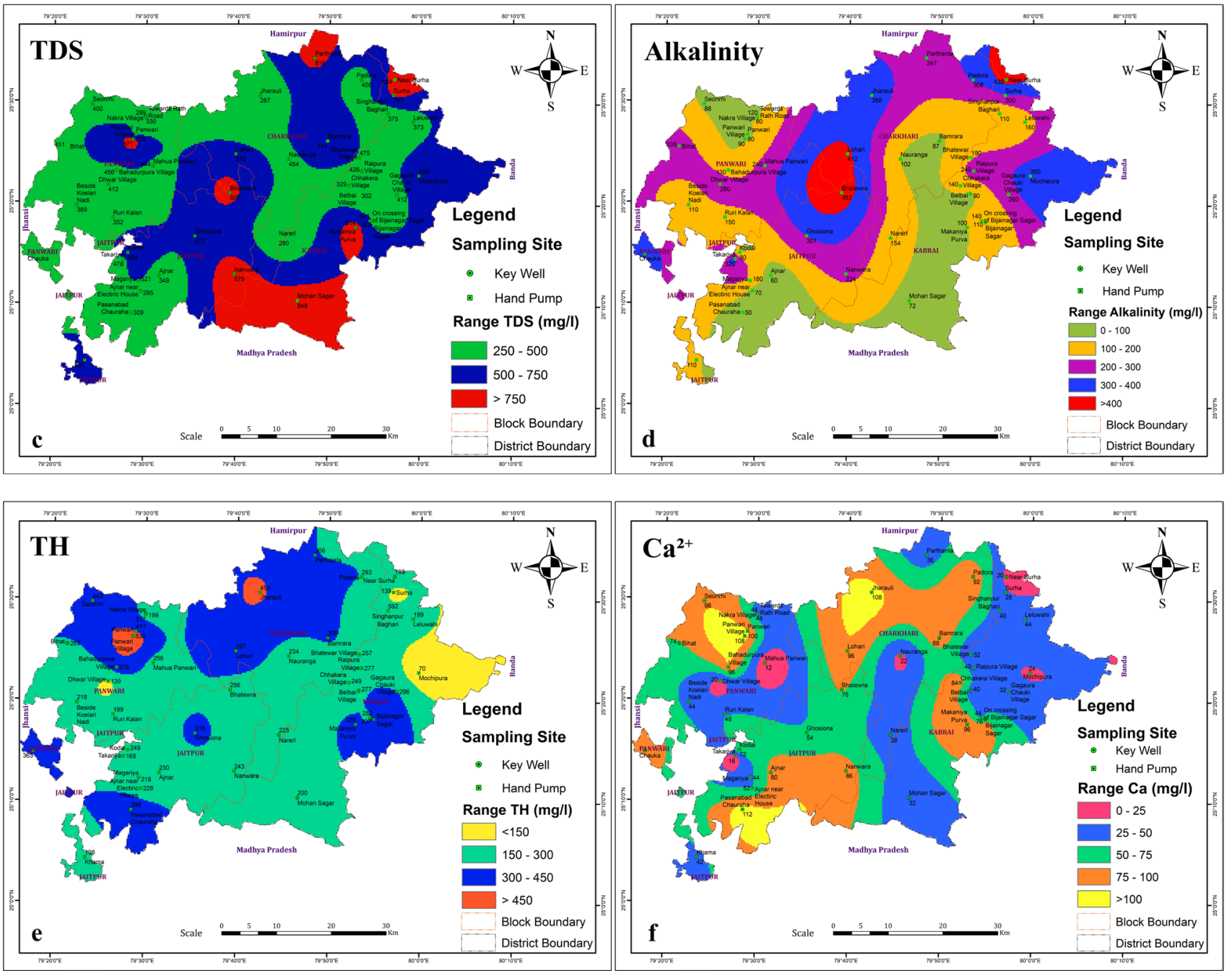

Fig. 2 a-b Spatial distribution map of $\mathrm{pH}$ and EC. $\mathbf{c}-\mathbf{h}$ Spatial distribution map of TDS, AK, TH, $\mathrm{Ca}^{2+}, \mathrm{Mg}^{2+}$ and Na $\mathrm{Na}^{+}$i $-\mathbf{n}$ : spatial distribution map of $\mathrm{K}^{+}, \mathrm{HCO}_{3}^{-}, \mathrm{SO}_{4}^{2-}, \mathrm{Cl}^{-}, \mathrm{F}^{-}$and $\mathrm{NO}_{3}^{-}$. o-t Spatial distribution map of $\mathrm{Cu}, \mathrm{Mn}, \mathrm{Ag}, \mathrm{Zn}, \mathrm{Fe}$ and $\mathrm{Ni}$ 


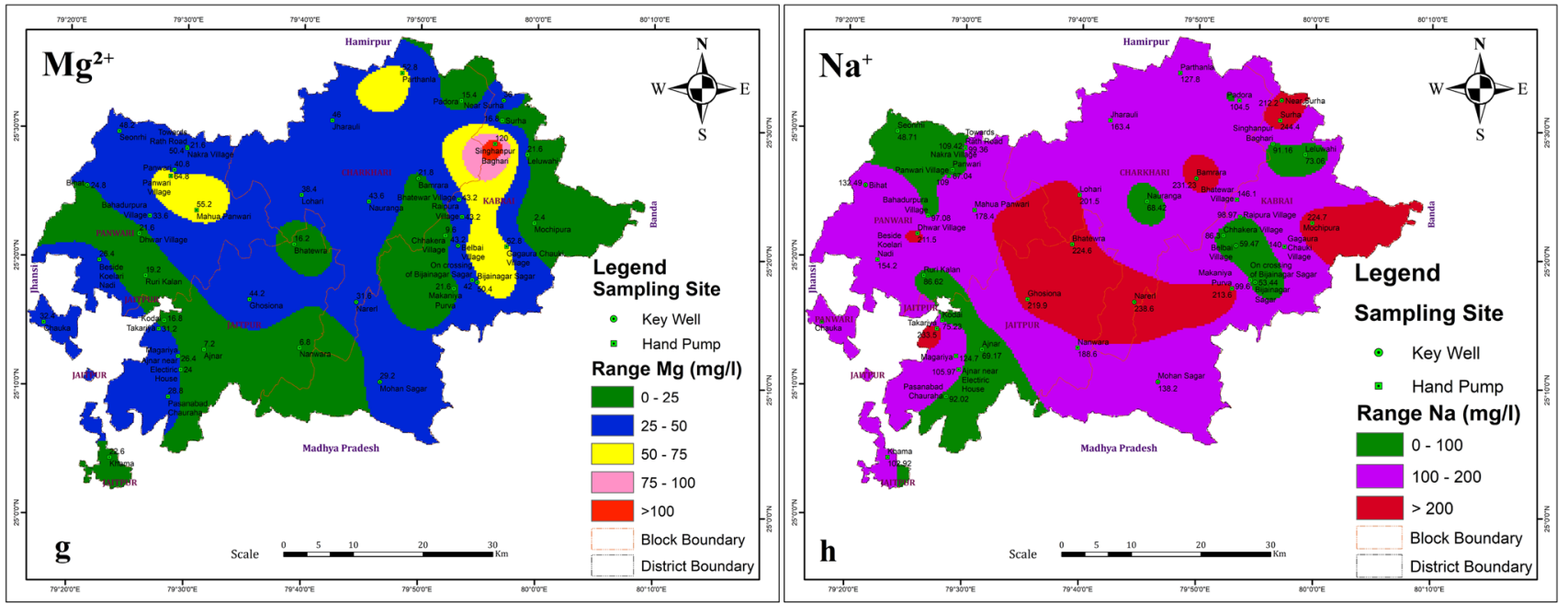

(c-h) spatial distribution map of TDS, AK, TH, $\mathrm{Ca}^{2+}, \mathrm{Mg}^{2+}$ and $\mathrm{Na}^{+}$
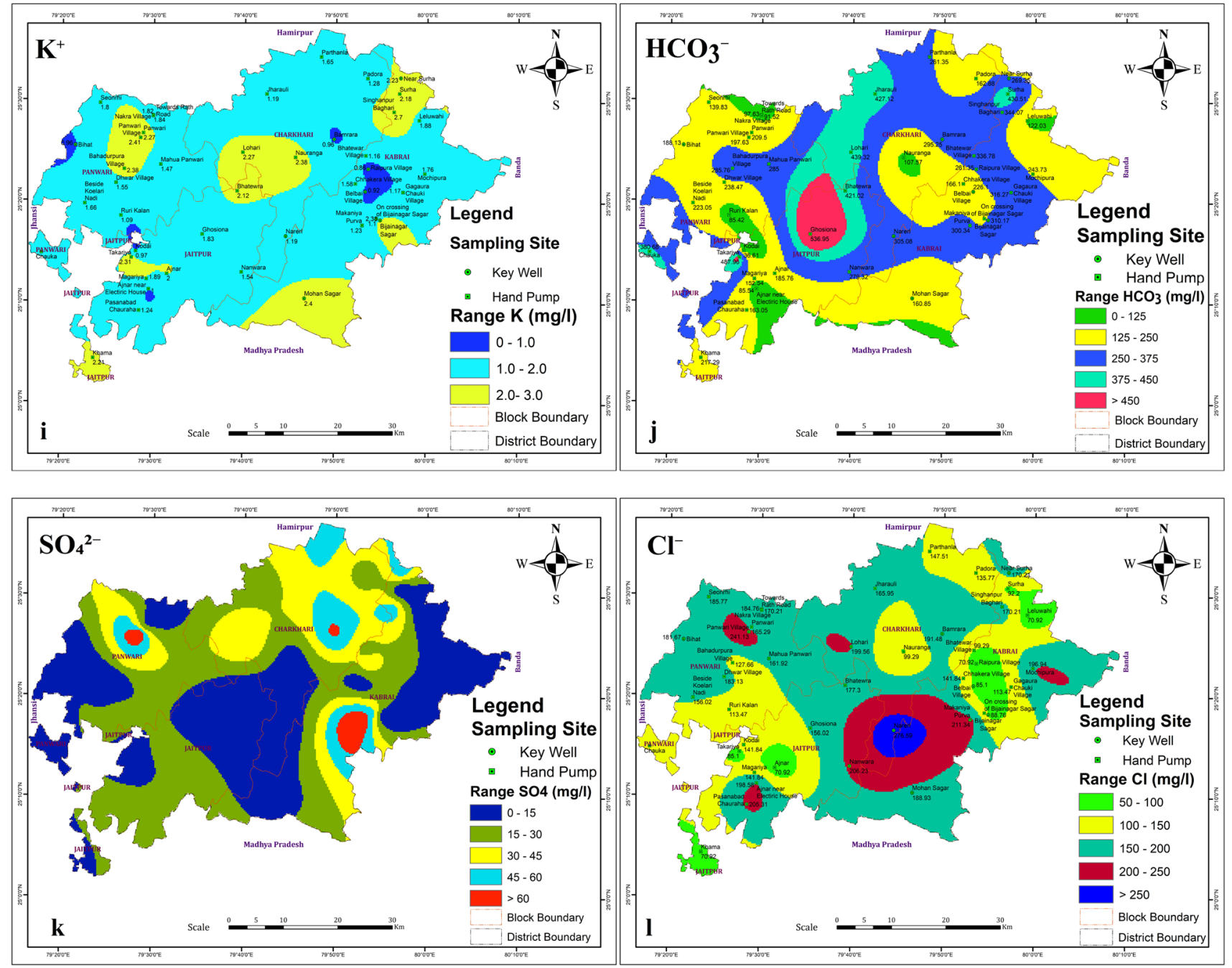

Fig. 2 (continued) 

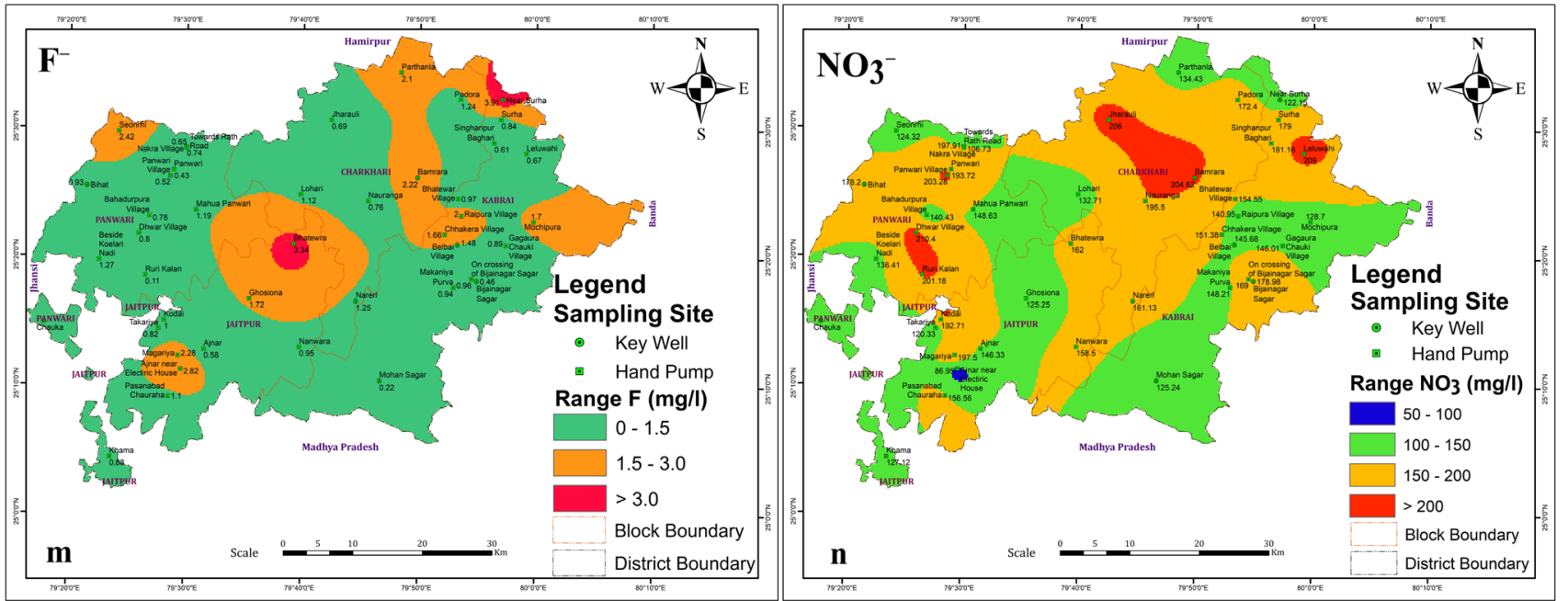

(i-n) spatial distribution map of $\mathrm{K}^{+}, \mathrm{HCO}_{3}{ }^{-}, \mathrm{SO}_{4}{ }^{2-}, \mathrm{Cl}^{-}, \mathrm{F}^{-}$and $\mathrm{NO}_{3}{ }^{-}$
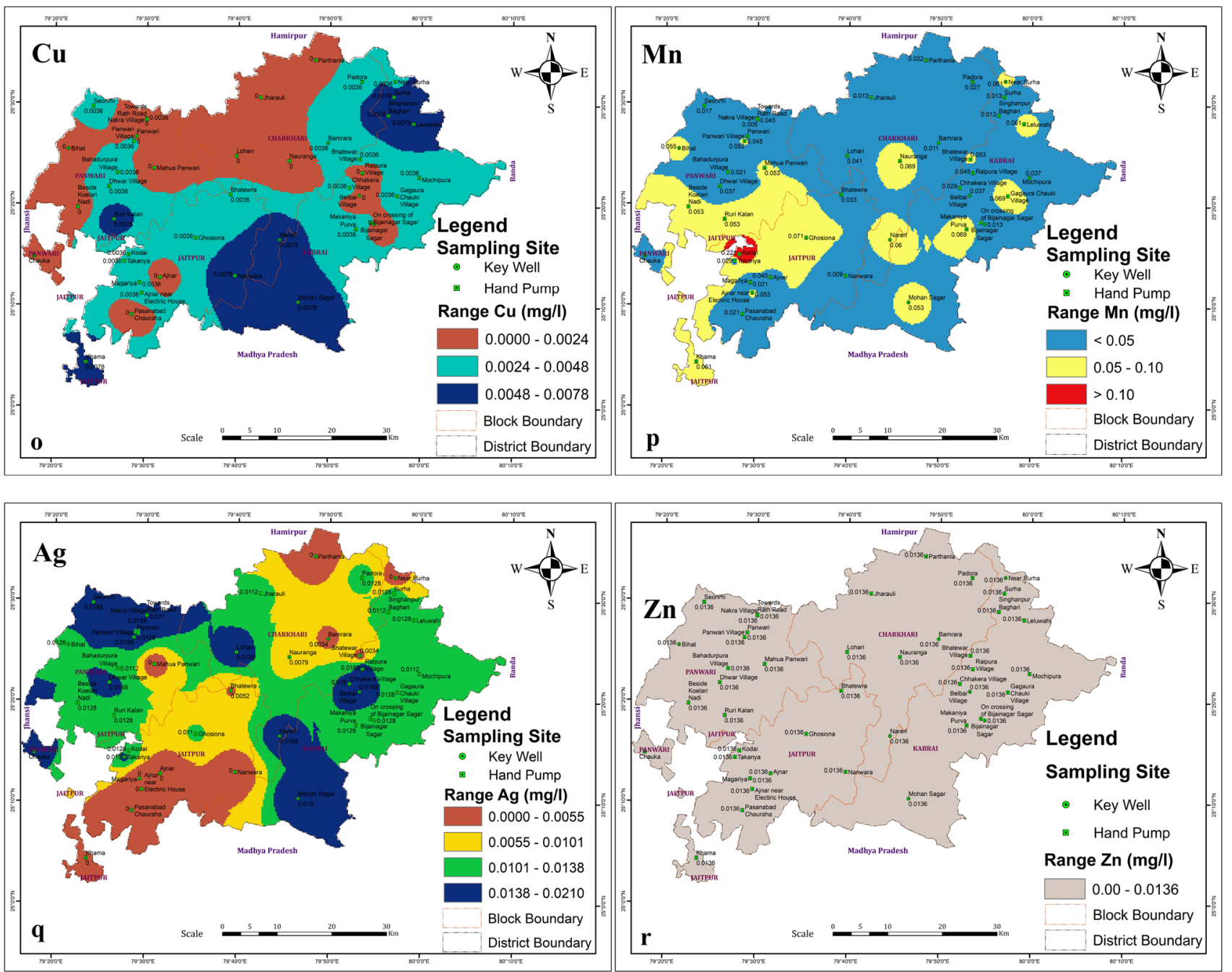

Fig. 2 (continued) 


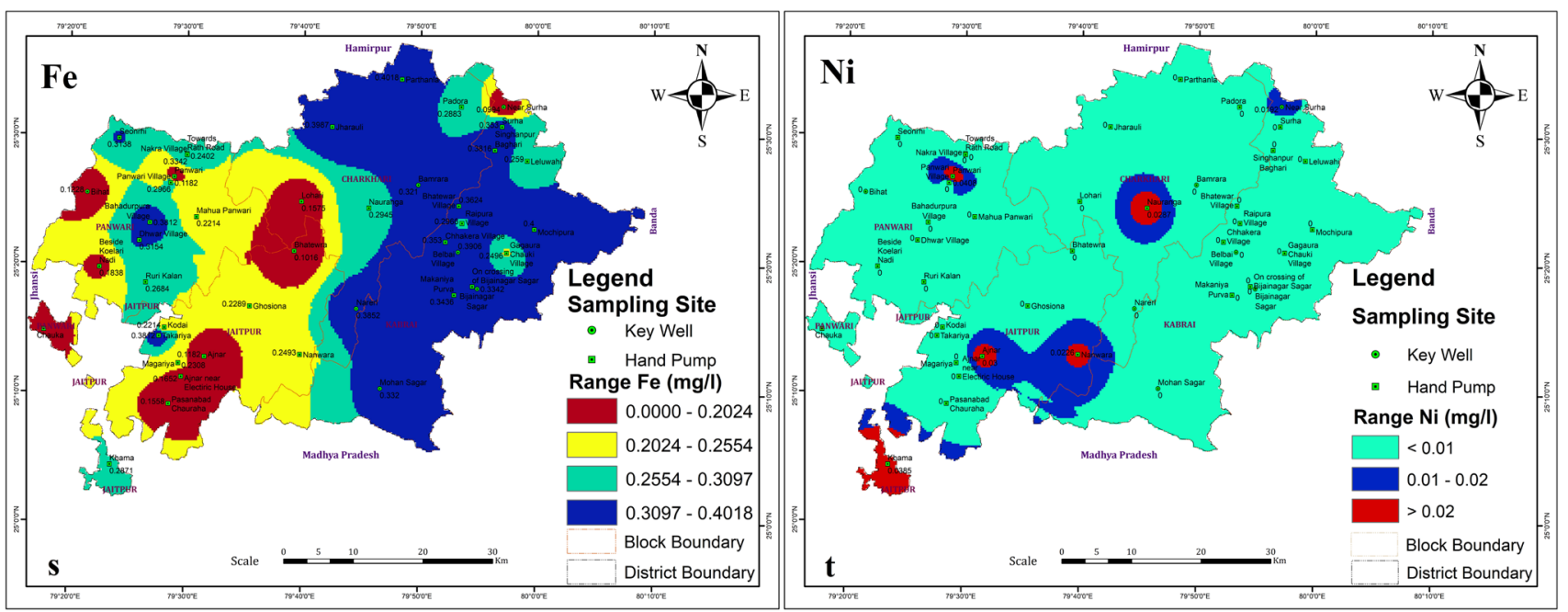

(o-t) spatial distribution map of $\mathrm{Cu}, \mathrm{Mn}, \mathrm{Ag}, \mathrm{Zn}, \mathrm{Fe}$ and $\mathrm{Ni}$

Fig. 2 (continued)

unpredictable contamination and subsequent changes in the characteristics of groundwater. Water samples were filtered using Whatman 42 filter paper (pore size $2.5 \mu \mathrm{m}$ ) prior to collection in the bottle. The sample was kept in the ice-box (portable) and brought to NABL accredited (ISO 17,025: 2017) laboratory of Central Ground Water Board (CGWB), Lucknow and Department of Soil Science \& Agricultural Chemistry, Banaras Hindu University, Varanasi, UP, India. The samples were stored in a chemical laboratory at temperature $4-5{ }^{\circ} \mathrm{C}$. The samples for metallic parameters were added $2 \mathrm{ml}$ elemental grade nitric acid to obtain the $\mathrm{pH} 2-3$ after acidification. The samples were pre-filtered in the laboratory to carry out the analysis. In the present study, a total of 20 groundwater quality parameters of forty-three samples were analysed as per test standard methods (APHA 2017) in the laboratory except for unstable parameters viz. hydrogen ion concentration $(\mathrm{pH})$, electrical conductivity (EC) and total dissolved solids (TDS) which are determined by portable device (pH-meter, EC-meter and TDS-meter) in situ. Alkalinity (AK), Total hardness (TH), calcium $\left(\mathrm{Ca}^{2+}\right)$, magnesium $\left(\mathrm{Mg}^{2+}\right)$, bicarbonate $\left(\mathrm{HCO}_{3}^{-}\right)$and chloride $\left(\mathrm{Cl}^{-}\right)$ were analysed using volumetric titrations; sodium $\left(\mathrm{Na}^{+}\right)$ and potassium $\left(\mathrm{K}^{+}\right)$were analysed using systronics flame photometer model 129; nitrate $\left(\mathrm{NO}_{3}^{-}\right)$, fluoride $\left(\mathrm{F}^{-}\right)$, sulfate $\left(\mathrm{SO}_{4}^{2-}\right)$, were analysed using shimadzu 1800 spectrophotometer. Prior to analysis of the heavy metals viz. copper $(\mathrm{Cu})$, manganese $(\mathrm{Mn})$, silver $(\mathrm{Ag})$, zinc $(\mathrm{Zn})$, iron $(\mathrm{Fe})$ and nickel $(\mathrm{Ni})$; the groundwater samples were acidified with 1:1 nitric acid and concentrated ten times. The samples were subjected to analysis using Shimadzu 6701 Atomic Absorption Spectrophotometer (AAS) on flame mode with hollow cathode lamps of metal under analysis. The concentration of metal is displayed on the monitor. The standards of the metallic parameters were prepared from National Institute of Standards and Technology (NIST) certified (Certified Reference Materials) CRM as per NABL guidelines of 17,025:2017.

The quality assurance and quality control (QA/QC) procedure of the data has been considered during the study. Approximately half of the volume $(500 \mathrm{ml})$ of samples were specially separated and checked in the laboratory to ensure QA/QC mechanisms. The accuracy of the chemical analysis has been validated by charge balance errors and samples $<5 \%$ error were considered.

The inverse distance weighted (IDW) interpolation technique used in this study is now-adays an effective tool for spatial interpolation of groundwater quality parameters leading to the generation of spatial distribution maps (Magesh et al. 2013; Kawo and Shankar 2018; Balamurugan et al. 2020b; Sarfo and Shankar 2020). The weights were assigned to various parameters at each location based on distance and were calculated, taking into consideration the closest specified locations. The distribution of each groundwater quality parameter has been demarcated in different zones on spatial distribution map viz. acceptable/desirable and permissible limits according to BIS $(2012,2015)$ and WHO (2017) for drinking purpose. The statistical analysis and correlation matrix of the analysed groundwater quality parameters have been laid down as shown in Tables 1 and 2, respectively.

\section{The water quality index (WQI)}

The WQI has been determined using the drinking water quality standard recommended by the World Health Organization (WHO 2017). The Water Quality Index has been 
Table 1 Statistical analysis of groundwater quality parameters and its coherence with BIS and WHO standards

\begin{tabular}{|c|c|c|c|c|c|c|}
\hline \multirow[b]{2}{*}{ Parameters (unit) } & \multicolumn{2}{|c|}{ Drinking-water standards } & \multicolumn{4}{|c|}{ Statistical analysis of observed value } \\
\hline & BIS $(2012,2015)^{*}$ & WHO (2017) & Min & Max & Mean & $\operatorname{SD}(\sigma)$ \\
\hline pH (On Scale) & $6.5-8.5$ & $7-8$ & 6.810 & 8.320 & 7.812 & 0.458 \\
\hline $\mathrm{EC}(\mu \mathrm{S} / \mathrm{cm})$ & $750-3000$ & - & 286.000 & 1162.00 & 624.674 & 253.052 \\
\hline TDS (mg/l) & $500-2000$ & $600-1000$ & 280.000 & 879.000 & 504.995 & 189.642 \\
\hline Alkalinity (mg/l) & $200-600$ & - & 50.000 & 452.000 & 189.767 & 112.927 \\
\hline $\mathrm{TH}$ as $\mathrm{CaCO}_{3}(\mathrm{mg} / \mathrm{l})$ & $200-600$ & 200 & 70.000 & 592.000 & 284.620 & 105.034 \\
\hline $\mathrm{Ca}^{2+}(\mathrm{mg} / \mathrm{l})$ & $75-200$ & $100-300$ & 12.000 & 112.000 & 58.744 & 29.854 \\
\hline $\mathrm{Mg}^{2+}(\mathrm{mg} / \mathrm{l})$ & $30-100$ & - & 2.400 & 120.000 & 33.600 & 19.969 \\
\hline $\mathrm{Na}^{+}(\mathrm{mg} / \mathrm{l})$ & - & $50-200$ & 48.710 & 244.400 & 136.400 & 60.210 \\
\hline $\mathrm{K}^{+}(\mathrm{mg} / \mathrm{l})$ & - & - & 0.860 & 2.700 & 1.675 & 0.530 \\
\hline $\mathrm{HCO}_{3}^{-}(\mathrm{mg} / \mathrm{l})$ & $300-600$ & - & 36.610 & 536.950 & 247.646 & 117.307 \\
\hline $\mathrm{SO}_{4}^{2-}(\mathrm{mg} / \mathrm{l})$ & $200-400$ & 250 & 2.230 & 75.170 & 22.387 & 19.306 \\
\hline $\mathrm{Cl}^{-}(\mathrm{mg} / \mathrm{l})$ & $250-1000$ & 250 & 70.920 & 276.590 & 150.642 & 49.555 \\
\hline $\mathrm{F}^{-}(\mathrm{mg} / \mathrm{l})$ & $1-1.5$ & 1.5 & 0.110 & 3.910 & 1.223 & 0.813 \\
\hline $\mathrm{NO}_{3}^{-}(\mathrm{mg} / \mathrm{l})$ & 45 & 50 & 86.950 & 210.400 & 159.067 & 31.507 \\
\hline $\mathrm{Cu}(\mathrm{mg} / \mathrm{l})$ & $0.05-1.5$ & 2 & 0.000 & 0.008 & 0.003 & 0.003 \\
\hline Mn (mg/l) & $0.1-0.3$ & $0.1-0.4$ & 0.005 & 0.221 & 0.044 & 0.034 \\
\hline $\mathrm{Ag}(\mathrm{mg} / \mathrm{l})$ & 0.1 & 0.1 & 0.000 & 0.021 & 0.011 & 0.007 \\
\hline $\mathrm{Zn}(\mathrm{mg} / \mathrm{l})$ & $5.0-15$ & $3-5$ & 0.014 & 0.014 & 0.014 & 0.000 \\
\hline $\mathrm{Fe}(\mathrm{mg} / \mathrm{l})$ & 1.0 & 0.3 & 0.099 & 0.402 & 0.275 & 0.092 \\
\hline $\mathrm{Ni}(\mathrm{mg} / \mathrm{l})$ & 0.02 & 0.07 & 0.000 & 0.041 & 0.004 & 0.011 \\
\hline
\end{tabular}

*The lower value denotes acceptable/desirable limit and the higher value denotes the permissible limit in the absence of alternate source (BIS, 2012, 2015) calculated using the weighted arithmetic method, which was originally proposed by Horton (1965) and developed by Brown et al. (1972). The weighted arithmetic water quality index (WQI) is represented in the following way:

$W Q I=\sum_{i=1}^{n} W_{i} Q_{i} / \sum_{i=1}^{n} W_{i}$

where $\mathbf{n}=$ number of variables or parameters, $\mathbf{W}_{\mathbf{i}}=$ unit weight for the $i$ th parameter, $\mathbf{Q}_{\mathbf{i}}=$ quality rating (sub-index) of the $i$ th water quality parameter.

The unit weight $\left(\mathbf{W}_{\mathbf{i}}\right)$ of the various water quality parameters are inversely proportional to the recommended standards for the corresponding parameters.

$\mathbf{W}_{\mathbf{i}}=\mathbf{K} / \mathbf{S}_{\mathbf{n}}$

where, $\mathbf{W}_{\mathbf{i}}=$ unit weight for the $i$ th parameter, $\mathbf{S}_{\mathbf{n}}=$ standard value for $i$ th parameters, $\mathbf{K}=$ proportional constant,

The value of $\mathbf{K}$ has been considered ' $\mathbf{1}$ ' here and is calculated using the mentioned equation below:

$K=1 / \Sigma\left(1 / S_{n}\right)$

According to Brown et al. (1972), the value of quality rating or sub-index $\left(\mathbf{Q}_{\mathbf{i}}\right)$ is calculated using the equation as given below:
$\mathbf{Q}_{\mathbf{i}}=\mathbf{1 0 0}\left[\left(\mathbf{V}_{\mathbf{0}}-\mathbf{V}_{\mathbf{i}}\right) /\left(\mathbf{S}_{\mathbf{n}}-\mathbf{V}_{\mathbf{i}}\right)\right]$

where $\mathbf{V}_{\mathbf{o}}=$ observed value of $i$ th parameter at a given sampling site, $\mathbf{V}_{\mathbf{i}}=$ ideal value of $i$ th parameter in pure water, $\mathbf{S}_{\mathbf{n}}$ $=$ standard permissible value of $i$ th parameter.

All the ideal values $\left(\mathrm{V}_{\mathrm{i}}\right)$ are taken as zero for drinking water except $\mathrm{pH}$ and dissolved oxygen (Tripathy and Sahu 2005). In case of $\mathrm{pH}$, the ideal value is 7.0 (for natural/ pure water) while the permissible value is 8.5 (for polluted water). Similarly, for dissolved oxygen, the ideal value is $14.6 \mathrm{mg} / \mathrm{L}$ while the standard permissible value for drinking water is $5 \mathrm{mg} / \mathrm{L}$. Therefore, the quality rating for $\mathrm{pH}$ and Dissolved Oxygen are calculated from the equations respectively as shown below:

$\mathrm{Q}_{\mathrm{pH}}=100\left[\left(V_{\mathrm{pH}^{-}}-\mathbf{7 . 0}\right) /(8.5-7.0)\right]$

$Q_{\mathrm{do}}=100\left[\left(V_{\mathrm{do}} 14.6\right) /(5.0-14.6)\right]$

where, $\boldsymbol{V}_{\mathbf{p H}}=$ observed value of $\mathrm{pH}, \boldsymbol{V}_{\mathbf{d o}}=$ observed value of dissolved oxygen.

If, $Q_{i}=0$ implies complete absence of contaminants while $0<\mathrm{Q}_{\mathrm{i}}<100$ implies that, the contaminants are within the prescribed standard. When $\mathrm{Q}_{\mathrm{i}}>100$ implies that, the contaminants are above the standards. 


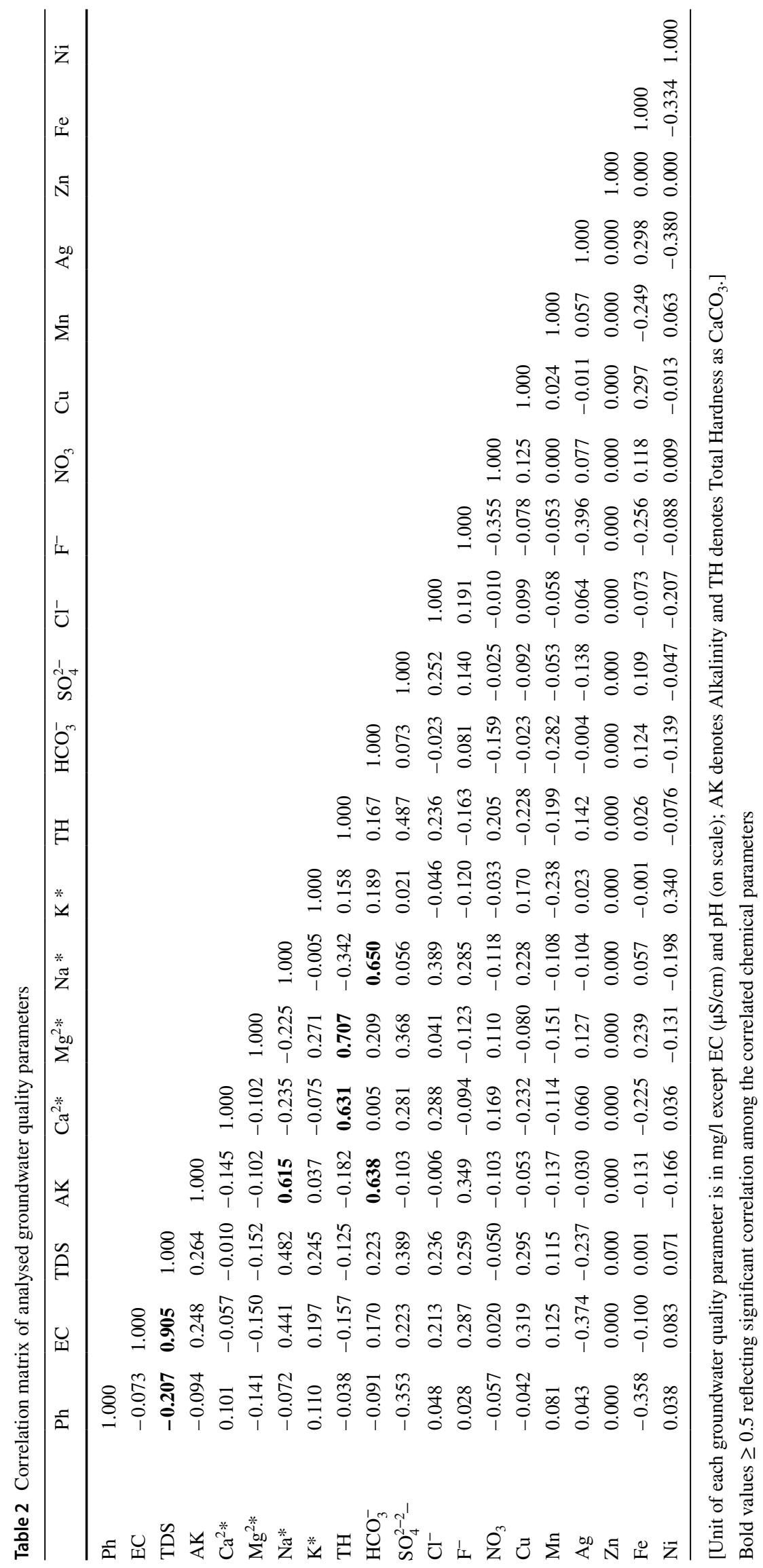


The classification of water quality, based on its water quality index (WQI) after Brown et al. (1972); Chatterjee and Raziuddin (2002) and Shankar and Kawo (2019) have been considered here in this study for further reference which is mentioned in Table 3.

\section{Result and discussion}

\section{Groundwater quality parameters}

In this study based on the selected parameters as discussed above the groundwater quality maps have been prepared with the help of ArcGIS software 10.1 as shown in Fig. 2a-t. In the following lines, the various parameters considered in the study are being discussed: The Bureau of Indian Standard (BIS 2012, 2015) and World Health Organization (WHO 2017) of drinking water standards have been considered as a reference in this study.

\section{Hydrogen ion concentration $(\mathrm{pH})$}

It is an important indicator for assessing the quality and pollution of any aquifer system as it is closely related to other chemical constituents of water. The presence of hydrogen ion concentration is measured in terms of $\mathrm{pH}$ range. Water, in its pure form shows a neutral $\mathrm{pH}$ which indicates hydrogen ion concentration. In the present study, the range of $\mathrm{pH}$ varies between 6.81 (minimum) to 8.32 (maximum) which is within the acceptable limit (6.5-8.5, avg: 7.81) indicating the alkaline nature of groundwater (ideal range of $\mathrm{pH}$ for human consumption: 6.5-8.5).

\section{Electrical conductivity (EC)}

In fact, it is a measure of the ability of any substance or solution to conduct electrical current through the water. EC is directly proportional to the dissolved material in a water sample. The desirable limit of EC for drinking purpose is $750 \mu \mathrm{S} / \mathrm{cm}$. In this study, the electrical conductivity varies between 286 and $1162 \mu \mathrm{S} / \mathrm{cm}$. High EC at some sites

Table 3 Classification of water quality and status based on weighted arithmetic WQI Method

\begin{tabular}{ll}
\hline WQI & Rating Class \\
\hline $0-25$ & Excellent \\
$26-50$ & Good \\
$51-75$ & Poor \\
$76-100$ & Very Poor \\
$>100$ & Unsuitable \\
\hline
\end{tabular}

Source: Brown et al. (1972), Chatterjee and Raziuddin (2002) suggests the mixing of sewage in groundwater as these sites are near dense urbanization.

\section{Total dissolved solids (TDS)}

The weight of residue expresses it after a water sample is evaporated to dry state. It includes calcium, magnesium, sodium, potassium, carbonate, bicarbonate, chloride and sulfate. In the present study, it ranges between 280 to $879 \mathrm{mg} / \mathrm{l}$ ( $<500 \mathrm{mg} / \mathrm{l}$ TDS for potable water as per BIS.). The agricultural practices, residential runoff, leaching of soil causing contamination and point source water pollution discharge from industrial or sewage treatment plants are the primary sources for TDS (Boyd 2000).

\section{Alkalinity (AK)}

It is a measure of the carbonate, bicarbonate and hydroxide ions present in water. The desirable limit of alkalinity in potable water is $200 \mathrm{mg} / \mathrm{l}$, above which the taste of water becomes unpleasant. In the study area, the alkalinity ranges between 50 to $452 \mathrm{mg} / \mathrm{l}$, which is within the permissible limit $(600 \mathrm{mg} / \mathrm{l})$.

\section{Total hardness (TH)}

It is the amount of dissolved calcium and magnesium in the water. Water moving through soil and rock dissolves naturally occurring minerals and carries them into the groundwater as it is a great solvent for calcium and magnesium. In this study, hardness ranges between 70 to $592 \mathrm{mg} / \mathrm{l}$, which is within the permissible limits $(600 \mathrm{mg} / \mathrm{l})$. The high concentration of $\mathrm{TH}$ in groundwater may cause heart disease and kidney stone in human beings.

\section{Calcium $\left(\mathrm{Ca}^{2+}\right)$}

It enters into the aquifer system from the leaching of calcium bearing minerals. In the study area, the calcium concentration ranges from 12 to $112 \mathrm{mg} / \mathrm{l}$ and is within the permissible limit $(200 \mathrm{mg} / \mathrm{l})$. The lesser concentration of $\mathrm{Ca}^{2+}$ in the groundwater satisfies the chemical weathering and dissolution of fluorite, consequently resulting in an increase of fluoride concentration.

\section{Magnesium $\left(\mathrm{Mg}^{2+}\right)$}

It is an important parameter responsible for the hardness of the water. In the study area, the concentration ranges between 2.4 to $120 \mathrm{mg} / \mathrm{l}$ and is present in little excess of the permissible limit $(100 \mathrm{mg} / \mathrm{l})$. 


\section{Sodium $\left(\mathrm{Na}^{+}\right)$}

It is a highly reactive alkali metal. It is present in most of the groundwater. Many rocks and soils contain sodium compounds, which easily dissolves to liberate sodium in groundwater. In the study area, it ranges from 48.71 to $244.4 \mathrm{mg} / \mathrm{l}$. The high concentration of $\mathrm{Na}^{+}$indicates weathering of rockforming minerals i.e., silicate minerals (alkali feldspars) and/ or dissolution of soil salts present therein due to evaporation (Stallard and Edmond 1983). In the aquifers, the high $\mathrm{Na}^{+}$ concentration in groundwater may be related to the mechanism of cation exchange (Kangjoo Kim and Seong-Taekyun 2005).

\section{Potassium $\left(\mathrm{K}^{+}\right)$}

It is present in many minerals and most of the rocks. Many of these rocks are relatively soluble and releases potassium, the concentration of which increases with time in groundwater. In this study, it varies between 0.87 to $2.7 \mathrm{mg} / \mathrm{l}$.

Bicarbonate $\left(\mathrm{HCO}_{3}^{-}\right)$It is produced by the reaction of carbon dioxide with water on carbonate rocks viz. limestone and dolomite. The carbon-dioxide present in the soil reacts with the rock-forming minerals is responsible for the presence of bicarbonate, producing an alkaline environment in the groundwater. In the study area it varies between 36.61 to $536.95 \mathrm{mg} / \mathrm{l}$ and is within the permissible limit of $600 \mathrm{mg} / \mathrm{l}$.

Sulfate $\left(\mathrm{SO}_{4}^{2-}\right)$ It is dissolved and leached from rocks containing gypsum, iron sulfides, and other sulfur bearing compounds. In the present study, it ranges between the 2.23 to $75.17 \mathrm{mg} / \mathrm{l}$, which is well within the acceptable limit of $200 \mathrm{mg} / \mathrm{l}$.

Chloride $\left(\mathrm{Cl}^{-}\right)$In the present study the $\mathrm{Cl}^{-}$ranges between 70.92 to $276.59 \mathrm{mg} / \mathrm{l}$ which exceed the permissible limit $(250 \mathrm{mg} / \mathrm{l})$. The higher value of chlorine in groundwater makes it hazardous to human health (Pius et al. 2012; SadatNoori et al. 2014).

Fluoride $\left(\mathrm{F}^{-}\right)$In groundwater fluoride is geogenic in nature. It is the lightest halogen, and one of the most reactive elements (Kaminsky et al. 1990). It usually occurs either in trace amounts or as a major ion with high concentration (Gaciri and Davies 1993; Apambire et al. 1997; Fantong et al. 2010). The groundwater contains fluorides released from various fluoride-bearing minerals mainly as a result of groundwater-host rock interaction. The study area comprising granite, granitic gneiss etc. is commonly found to contain fluorite $\left(\mathrm{CaF}_{2}\right)$ as an accessory mineral (Ozsvath 2006; Saxena and Ahmed 2003) which plays a significant role in controlling the geochemistry of fluo- ride (Deshmukh et al. 1995). In addition to fluorite it is also abundant in other rock-forming minerals like apatite, micas, amphiboles, and clay minerals (Karro and Uppin 2013; Narsimha and Sudarshan 2013; Naseem et al. 2010; Jha et al. 2010; Rafique et al. 2009; Carrillo-Rivera et al. 2002). In the present study, the fluoride concentration ranges from 0.11 to $3.91 \mathrm{mg} / \mathrm{l}$. The concentration of fluoride exceeds the permissible limit $(1.5 \mathrm{mg} / \mathrm{l})$ in about $25 \%$ of the groundwater samples.

Nitrate $\left(\mathrm{NO}_{3}^{-}\right)$Nitrate is naturally occurring ions and is a significant component in the nitrogen cycle. However, nitrate ion in groundwater is undesirable as it causes Methaemoglobinaemia in infants less than 6 months of age (Egereonu and Nwachukwu 2005). In general, its higher concentration causes health hazards if present beyond the permissible limit, $45 \mathrm{mg} / \mathrm{l}$ (Kumar et al. 2012, 2014). In the study area, its concentration ranges from 86.95 to $210.4 \mathrm{mg} / \mathrm{l}$. It is in excess of the permissible limits throughout the study area. The higher values of nitrate in potable water increases the chances of gastric ulcer/cancer, and other health hazards to infants and pregnant women (Rao 2006) also birth malformations and hypertension (Majumdar and Gupta 2000). The area under study is granite-gneiss terrain where the atmospheric nitrogen is fixed and added to the soil as ammonia through lightning storms, bacteria present in soil and root of plants. Further, animal wastes, plants and animals remain also undergo ammonification in the soil producing ammonia which undergoes nitrification/ammonia oxidation by Nitrosomonas and Nitrobacter bacteria to form nitrate (Rivett et al. 2008; Galloway et al. 2004). Granitic rocks contain nitrogen concentrations up to $250 \mathrm{mg} \mathrm{Nkg}^{-1}$ with ammonium partitioned into the orthoclase feldspar to a greater extent than muscovite or biotite (Boyd et al. 1993). Geologic nitrogen (nitrogen contained in bedrock) contribute to the ecosystem with nitrogen saturation (more nitrogen available than required by biota) leading to leaching of nitrogen and consequently elevating nitrate concentrations in groundwater (Dahlgren 1994; Holloway et al. 1998). Nitrogen released through weathering has a greater impact on soil and water quality. Also, denitrification is significant in modifying the level to which nitrogen released through weathering of bedrock influencing the supply of nitrate in groundwater (McCray et al. 2005).

Copper $(\mathrm{Cu})$ It is a naturally occurring metal in rock, soil, plants, animals, and groundwater in very less concentration. The concentration of $\mathrm{Cu}$ may get enriched into the groundwater through quarrying and mining activities, farming practices, manufacturing operations and municipal or industrial waste released. $\mathrm{Cu}$ gets into drinking water either by contaminating of well water or corrosion of copper pipes in case of water is acidic. In this study, 
it ranges between 0 and $0.0078 \mathrm{mg} / \mathrm{l}$, which is within the permissible limit $(0.05 \mathrm{mg} / \mathrm{l})$.

Manganese (Mn) It occurs naturally in groundwater, especially in an anaerobic environment. The concentrations of $\mathrm{Mn}$ in groundwater is dependent upon rainfall chemistry, aquifer lithology, geochemical environment, groundwater flow paths and residence time, etc. which may vary significantly in space and time. It may be released by the leaching of the overlying soils and minerals in underlying rocks as well as from the minerals of the aquifer itself in groundwater. In the present study, manganese ranges between 0.005 and $0.221 \mathrm{mg} / \mathrm{l}$, which is within the permissible limit $(0.3 \mathrm{mg} / \mathrm{l})$.

Silver It naturally occurs usually in the form of insoluble and immobile oxides, sulfides and some salts. It is rarely present in groundwater, surface water and drinking water at concentrations above $5 \mu \mathrm{g} / \mathrm{litre}$ (WHO 2017). In the present study, the silver ranges between 0.000 and $0.021 \mathrm{mg} / \mathrm{l}$, which is within the permissible limit $(0.1 \mathrm{mg} / \mathrm{l})$.

Zinc Though it occurs in significant quantities in rocks, groundwater seldom contains zinc above $0.1 \mathrm{mg} / \mathrm{l}$. In the present study, the groundwater shows the negligible concentration of $\mathrm{Zn}(0.0136 \mathrm{mg} / \mathrm{l})$ which is well within the acceptable limit $(5 \mathrm{mg} / \mathrm{l})$.

Iron (Fe) The most common sources of iron in groundwater is weathering of iron-bearing minerals and rocks. The iron occurs naturally in the reduced $\mathrm{Fe}^{2+}$ state in the aquifer, but its dissolution increases its concentration in groundwater. Iron in this state is soluble and generally does not create any health hazard. If $\mathrm{Fe}^{2+}$ state is oxidised to $\mathrm{Fe}^{3+}$ state in contact with atmospheric oxygen or by the action of iron-related bacteria which forms insoluble hydroxides in groundwater. So, the concentration of iron in groundwater is often higher than those measured in surface water. In the present study, the iron ranges between 0.0994 and $0.4018 \mathrm{mg} / \mathrm{l}$, which is within of the permissible limit $1.0 \mathrm{mg} / \mathrm{l}$ (BIS 2015).

Nickel (Ni) The primary source of nickel in groundwater is from the dissolution of nickel ore bearing rocks. The source of nickel in drinking water is leaching from metals in contact such as water supply pipes and fittings. $\mathrm{Ni}$ usually occurs in the divalent state, but oxidation states of $+1,+3$, or +4 may also exist in nature. In the study area, it ranges between 0 and $0.0408 \mathrm{mg} / \mathrm{l}$, and it crosses the permissible limit $(0.02 \mathrm{mg} / \mathrm{l})$.

\section{Statistical analysis, correlation matrix and relative weightage}

The relative weightage, general statistical analysis and correlation matrix of groundwater quality parameters are tabulated in Tables 4, 1 and 2, respectively. The correlation matrix of various 20 groundwater quality parameters, including 6 heavy metals was created and has been analysed using MS Excel 2016 Table 2. Out of these, eight parameters viz. TDS, EC, $\mathrm{Na}^{+}$, Alkalinity, $\mathrm{TH}, \mathrm{Ca}^{2+}, \mathrm{Mg}^{2+}, \mathrm{HCO}_{3}^{-}$are significantly correlated, reflecting more than 0.50 correlation value. Further, TDS vs $\mathrm{EC}, \mathrm{Na}^{+}$vs Alkalinity, $\mathrm{TH}$ as $\mathrm{CaCO}_{3}{ }^{-}$vs $\mathrm{Ca}^{2+}$ and $\mathrm{Mg}^{2+}, \mathrm{HCO}_{3}^{-}$vs Alkalinity and $\mathrm{Na}^{+}$ indicates most relevant correlation having a significant impetus on the overall assessment of the quality of groundwater than any other major radicals and physical parameters. However, the majority of quality parameters are positively correlated with each other. A critical analysis of the correlation matrix for the heavy metals indicates that $\mathrm{Cu}$ is positively correlated with $\mathrm{EC}, \mathrm{TDS}, \mathrm{Na}^{+}, \mathrm{K}^{+}, \mathrm{Cl}^{-}$and $\mathrm{NO}_{3}^{-}$. Similarly, $\mathrm{Mn}$ is positively correlated with $\mathrm{pH}, \mathrm{EC}$, TDS and $\mathrm{Cu}$. While, $\mathrm{Ag}$ is positively correlated with $\mathrm{pH}, \mathrm{Ca}^{2+}$, $\mathrm{Mg}^{2+}, \mathrm{K}^{+}, \mathrm{TH}, \mathrm{Cl}^{-}, \mathrm{NO}_{3}^{-}$and $\mathrm{Mn}$. Further, $\mathrm{Fe}$ is positively correlated with TDS, $\mathrm{Mg}^{2+}, \mathrm{Na}^{+}, \mathrm{TH}, \mathrm{HCO}_{3}^{-}, \mathrm{SO}_{4}^{2-}, \mathrm{NO}_{3}^{-}$, $\mathrm{Cu}$ and $\mathrm{Ag}$. Similarly, $\mathrm{Ni}$ is positively correlated with $\mathrm{pH}$, EC, TDS, $\mathrm{Ca}^{2+}, \mathrm{K}^{+}, \mathrm{NO}_{3}^{-}$and $\mathrm{Mn}$.

Table 4 Weightage $\left(\mathrm{w}_{\mathrm{i}}\right)$, relative weightage $\left(\mathrm{W}_{\mathrm{ir}}\right)$ and unit weightage $\left(\mathrm{W}_{\mathrm{i}}\right)$ of each groundwater quality parameter

\begin{tabular}{|c|c|c|c|c|}
\hline Parameters & BIS Standard & wi & Wir & $\mathrm{Wi}=\mathrm{K} / \mathrm{Sn}$ \\
\hline $\mathrm{Ph}$ (On Scale) & $6.5-8.5$ & 1 & 0.033333 & 0.001621 \\
\hline $\mathrm{EC}(\mu \mathrm{S} / \mathrm{cm})$ & $750-3000$ & 2 & 0.066667 & 0.000035 \\
\hline TDS (mg/l) & $500-2000$ & 1 & 0.033333 & 0.000021 \\
\hline $\mathrm{AK}(\mathrm{mg} / \mathrm{l})$ & $200-600$ & 1 & 0.033333 & 0.000053 \\
\hline TH (mg/l) & $200-600$ & 1 & 0.033333 & 0.000053 \\
\hline $\mathrm{Ca}^{2+}(\mathrm{mg} / \mathrm{l})$ & $75-200$ & 1 & 0.033333 & 0.000140 \\
\hline $\mathrm{Mg}^{2+}(\mathrm{mg} / \mathrm{l})$ & $30-100$ & 1 & 0.033333 & 0.000351 \\
\hline $\mathrm{Na}^{+}(\mathrm{mg} / \mathrm{l})$ & - & 2 & 0.066667 & 0.000211 \\
\hline $\mathrm{K}^{+}(\mathrm{mg} / \mathrm{l})$ & - & 1 & 0.033333 & 0.001054 \\
\hline $\mathrm{HCO}_{3}^{-}(\mathrm{mg} / \mathrm{l})$ & $300-600$ & 1 & 0.033333 & 0.000035 \\
\hline $\mathrm{SO}_{4}^{2-}(\mathrm{mg} / \mathrm{l})$ & $200-400$ & 1 & 0.033333 & 0.000053 \\
\hline $\mathrm{Cl}^{-}(\mathrm{mg} / \mathrm{l})$ & $250-1000$ & 1 & 0.033333 & 0.000042 \\
\hline $\mathrm{F}^{-}(\mathrm{mg} / \mathrm{l})$ & $1-1.5$ & 2 & 0.066667 & 0.010537 \\
\hline $\mathrm{NO}_{3}^{-}(\mathrm{mg} / \mathrm{l})$ & 45 & 3 & 0.100000 & 0.000234 \\
\hline $\mathrm{Cu}(\mathrm{mg} / \mathrm{l})$ & $0.05-1.5$ & 2 & 0.066667 & 0.210740 \\
\hline $\mathrm{Mn}(\mathrm{mg} / \mathrm{l})$ & $0.1-0.3$ & 2 & 0.066667 & 0.105370 \\
\hline $\mathrm{Ag}(\mathrm{mg} / \mathrm{l})$ & 0.1 & 2 & 0.066667 & 0.105370 \\
\hline $\mathrm{Zn}(\mathrm{mg} / \mathrm{l})$ & $5-15$ & 1 & 0.033333 & 0.002107 \\
\hline $\mathrm{Fe}(\mathrm{mg} / \mathrm{l})$ & 1.0 & 2 & 0.066667 & 0.035123 \\
\hline \multirow[t]{2}{*}{$\mathrm{Ni}(\mathrm{mg} / \mathrm{l})$} & 0.02 & 2 & 0.066667 & 0.526850 \\
\hline & & $\Sigma w_{i=} 30$ & $\Sigma W_{i r=1} 1$ & $\Sigma W_{i=} 1$ \\
\hline
\end{tabular}


The higher concentration of $\mathrm{Ni}, \mathrm{Fe}$ and $\mathrm{Mn}$ may trigger the presence of other heavy metals viz. $\mathrm{Pb}, \mathrm{Cd}$ and $\mathrm{Cr}$ which are very sensitive and significant heavy metal and needs to be observed carefully in future for groundwater quality in the study area. The presence of $\mathrm{Fe}, \mathrm{SO}_{4}^{2-}$ and $\mathrm{NO}_{3}^{-}$may trigger the presence of $\mathrm{Cd}$ (Chaurasia et al. 2018).

\section{Spatial distribution pattern}

The spatial distribution pattern of the contour maps of the groundwater quality parameters have been generated as represented in Fig. 2a-t. The spatial distribution pattern of the $\mathrm{pH}$ indicates that the central part along NW-SE across the district with some scattered small patches throughout indicating the presence of alkaline groundwater (Fig. 2a). In acidic water, fluoride is adsorbed on a clay surface, while in alkaline water, fluoride is desorbed from solid phases; therefore, alkaline $\mathrm{pH}$ is more favourable for fluoride dissolution, (Keshavarzi et al. 2010; Rafique et al. 2009; Saxena and Ahmed 2003; Rao 2009; Ravindra and Garg 2007; Vikas et al. 2009). The southern portion of the district in Kabrai Block is having high TDS (>750 mg/l) in groundwater (Fig. 2c) due to poor fluxing and highly weathered rock formations. Similarly, EC is mainly highest (>900 mg/l) in the southern part with small scattered patches in central and NE part of the district (Fig. 2b). This is in consonance with the higher TDS (significant positive correlation with EC) as evidenced by the correlation matrix of the quality parameters (Table 2). The alkalinity map clearly and significantly indicates that it is highest in the central part surrounded by gradually decreasing alkalinity outwards (Fig. 2d). The bicarbonates trigger the alkalinity in groundwater (Adams et al. 2001). The quality of groundwater in a major portion of the study area is alkaline in nature, indicating that the dissolved carbonates are predominantly in the form of bicarbonates. A positive correlation is observed between the alkalinity of groundwater and fluoride (Table 2), consequently releasing fluoride in the groundwater. The spatial distribution map of $\mathrm{Ca}^{2+}$ suggests varying concentration within permissible limit throughout the study area (Fig. 2f) due to the presence of alkali feldspar in granite. Similarly, $\mathrm{Mg}^{2+}$ is also distributed unevenly but falls within permissible limit with an exception in NE part of the district (Fig. 2g). The spatial distribution pattern of TH reflects that the study area is characterized by moderately hard groundwater.

Figure $2 \mathrm{e} \mathrm{The}^{2+}{ }^{2+}$ and $\mathrm{Mg}^{2+}$ ions present in the groundwater are possibly derived from leaching of calcium and magnesium bearing rock-formations in the study area. The fluoride in groundwater shows a negative correlation with $\mathrm{Ca}^{2+}$, indicating the high value of fluoride in groundwater in association with low $\mathrm{Ca}^{2+}$ content. The correlation matrix clearly marks a significant positive correlation among $\mathrm{Na}^{+}$, alkalinity and TDS, which is being reflected from their respective spatial distribution maps (Fig. 2c, $d$ and h). $\mathrm{Na}^{+}$ is highest in the central part (with small patches in the eastern part and insignificantly in the western part) which is in conformity with the alkalinity and TDS spatial distribution patterns. Although, the presence of $\mathrm{K}^{+}$is insignificant and its lower concentration within the permissible limit is covering a major portion of the district due to poor weathering of orthoclase. Its distribution pattern indicates conformity more or less with the TDS and $\mathrm{Na}^{+}$(Fig. 2c, h, and i). $\mathrm{HCO}_{3}^{-}$ is an important quality parameter showing significant positive correlation $(>0.50)$ with alkalinity and $\mathrm{Na}^{+}$(Table 2 ) which is also reflected in the spatial distribution pattern of these parameters (Fig. 2d, h, j). Although sulphate $\left(\mathrm{SO}_{4}^{2-}\right)$ is an important quality parameter. It is present within the permissible limit in the study.

area (Fig. 2k). Chloride is slightly in excess in a larger patch, particularly in SE-part of the study area which may cause a health hazard. It is revealed from the spatial distribution map of chloride (Fig. 21). This is due to poor fluxing and presence of halite mineral. Fluoride $\left(\mathrm{F}^{-}\right)$is an important quality parameter, especially with respect to the study area where it is present noticeably in scattered patches throughout the district. It is observed that mainly in NE part, the central part and SE part of the district the concentration of fluoride is in excess $(2.82 \mathrm{mg} / \mathrm{l}$ to $3.91 \mathrm{mg} / \mathrm{l})$ of permissible limit $1.5 \mathrm{mg} / \mathrm{l}$ (Fig. $2 \mathrm{~m})$. The higher concentration $(>3.0 \mathrm{mg} / \mathrm{l})$ of fluoride may lead to skeletal fluorosis (Raju et al 2009). Several factors viz. temperature, $\mathrm{pH}$, presence or absence of complexing or precipitating ions and colloids, the solubility of fluorine bearing minerals (biotite and apatite), anion exchange capacity of the aquifer $\left(\mathrm{OH}^{-}\right.$with $\left.\mathrm{F}^{-}\right)$, size and type of geological formations traversed by groundwater and the contact time during which water remains in contact with the formation are responsible for fluoride concentration in groundwater (Apambire et al. 1997). The lithology of fractured rock reveals that it contains more fluoride bearing minerals than massive rocks (Pandey et al. 2016). Nitrate $\left(\mathrm{NO}_{3}{ }^{-}\right)$in groundwater is mainly anthropogenic in nature which could be due to leaching from waste disposal, sanitary landfills, over-application of inorganic nitrate fertilizer or improper manure management practice (Chapman 1996). In this study, it is observed that nitrate is in excess of the permissible limits with varying degree of concentration throughout the district, causing health hazard (Fig. 2n). The area under study is granite-gneiss terrain where the atmospheric nitrogen is fixed and added to the soil as ammonia through lightning storms, bacteria present in soil and plants roots. Further, animal wastes, plants and animals remain also undergo ammonification in the soil producing ammonia which undergoes nitrification. The high values of nitrate in groundwater samples in the area may be due to unlined septic tanks and unplanned sewerage system that contaminates to the phreatic aquifer (Hei et al. 2020). Proper monitoring 
and concerned regulated effort are consistently required to get the assessment of nitrate impact on human health.

As far as heavy metals concentration in groundwater is concerned, $\mathrm{Cu}$ does not mark its noticeable presence (Fig. 2o). Another, naturally occurring quality parameter is Mn which shows its presence within the permissible limit (Fig. 2p). Silver and Zinc do not show any remarkable presence in the study area (Fig. $2 q$ and r). The study reveals a higher concentration of iron in groundwater in the Eastern part of the district due to secondary porosity and where ferrous $\left(\mathrm{Fe}^{2+}\right)$ ion usually occurs below the water table. The $\mathrm{Fe}^{2+}$ after converting into Ferric $\left(\mathrm{Fe}^{3+}\right)$ state, becomes harmful and precipitated. This condition can be avoided naturally by raising the water table through groundwater recharging the affected area (Fig. 2s). Nickel shows its remarkable presence in smaller patches in different areas (Fig. 2t) due to the presence of heavy minerals like rutile and apatite.

\section{Water quality index}

The water quality index (WQI) map has been prepared using ArcGIS 10.1 on the basis of the selectively chosen quality parameters to decipher the various quality classes viz. excellent, good, poor, very poor and unsuitable at each hydrostation for drinking purpose (Tables 3 and 5; Fig. 3). The WQI Map of the study area indicates that major portion is having excellent (0-25) quality of groundwater while very poor $(75-100)$ to unsuitable $(>100)$ quality is prevailing in small pockets in SW part (Fig. 3). The map clearly indicates that the quality of groundwater in Panwari Block belongs to excellent to good categories as for as potability for human consumption is concerned.

There is gradual variation in groundwater quality from very poor to excellent at the central part and outwards in the Charkhari Block. There is no noticeable change in the quality of groundwater except in the SW part of the Kabari Block. In the Jaitpur block, there is a significant.

variation in the quality class and the SW part (Nanwara, Ajnar and Khama) is characterized by poor, very poor and unsuitable categories (Fig. 3). Remaining part of the block falls under good to excellent groundwater quality. Overall, the quality of groundwater belongs to the excellent category in a major portion of the study area and is suitable for drinking as well as domestic uses.

\section{Hydro-chemical facies}

The major ions analysed are unevenly distributed and have been plotted on a Hill-Piper Trilinear diagram (Fig. 4). This diagram is comprised of two triangles at the base and one diamond shape at the top to represent the major significant cations and anions responsible for the nature of groundwater (Balamurugan et al. 2020a). The piper diagram is used to categorize groundwater into various six types such as $\mathrm{Ca}^{2+}-\mathrm{HCO}_{3}^{-}$type, $\mathrm{Na}^{+}-\mathrm{Cl}^{-}$type, mixed $\mathrm{Ca}^{2+}-\mathrm{Mg}^{2+}-\mathrm{Cl}^{-}$type, $\mathrm{Ca}^{2+}-\mathrm{Na}^{+}-\mathrm{HCO}_{3}^{-}$type, $\mathrm{Na}^{+}-\mathrm{HCO}_{3}^{-}$ type and $\mathrm{Ca}^{2+}{ }_{-} \mathrm{Cl}^{-}$type. A critical evaluation of the diagram reflects that $32.56 \%$ of the samples fall under $\mathrm{Na}^{+}-\mathrm{Cl}^{-}$type, $30.23 \%$ of the samples under mixed $\mathrm{Ca}^{2+}-\mathrm{Mg}^{2+}-\mathrm{Cl}^{-}$type, $16.28 \%$ of the samples under $\mathrm{Ca}^{2+}-\mathrm{HCO}_{3}^{-}$type, $13.95 \%$ of the samples under mixed $\mathrm{Ca}^{2+}-\mathrm{Na}^{+}-\mathrm{HCO}_{3}^{-}$type, $4.65 \%$ of the samples under $\mathrm{Na}^{+}-\mathrm{HCO}_{3}^{-}$type and $2.33 \%$ of the samples under $\mathrm{Ca}^{2+}{ }_{-} \mathrm{Cl}^{-}$type. Further, the observation reveals that the samples are distributed mainly into $\mathrm{Na}^{+}-\mathrm{Cl}^{-}$type, mixed $\mathrm{Ca}^{2+}-\mathrm{Mg}^{2+}-\mathrm{Cl}^{-}$type and $\mathrm{Ca}^{2+}-\mathrm{HCO}_{3}^{-}$type reflecting higher concentration of sodium and calcium bearing salt/mineral. Hydrochemistry of the analysed samples indicate that the major cations are present in order $\mathrm{Na}^{+}>\mathrm{Ca}^{2+}>\mathrm{Mg}^{2+}>\mathrm{K}^{+}$of mean abundance while anions are present in the mean abundance order of $\mathrm{HCO}_{3}^{-}>\mathrm{NO}_{3}^{-}>\mathrm{Cl}^{-}>\mathrm{SO}_{4}^{2-}>\mathrm{F}^{-}$(Table 1). This reveals that sodium, chloride and bicarbonate dominate the ionic concentration in the groundwater due to action of weathering of minerals like halite and dolomite as well as ion exchange process.

\section{Conclusion}

- The outcome of the present research in the hard rock area of the Bundelkhand region of India reveals that the groundwater has been deteriorated due to both geogenic and anthropogenic activities.

- The study area is comprised mainly of granite and alkali granite, specifically in extreme southern which is responsible for leaching of fluoride in groundwater.

- The thickness of overburden (loose soil and weathered rock) in the northern part of the study area is negligible. Therefore, there is a poor fluxing of groundwater which in turn triggers the concentration of TDS, fluoride and bicarbonate in groundwater.

- Anthropogenic activities like unlined septic tanks and unplanned sewerage system have triggered the nitrate concentration in groundwater, particularly in the central and northern part of the study area. The rest of the area is safe and has potable groundwater. In addition, the area under study is granite-gneiss terrain where the atmospheric nitrogen is fixed and added to the soil as ammonia through natural lightning, bacteria present in soil and plants roots. Further, ammonification of animal wastes, plants and animal remains produces ammonia which undergoes nitrification.

- Hydro-chemical facies reveal that the nature of groundwater is $\mathrm{Na}^{+}-\mathrm{Cl}^{-}$, mixed $\mathrm{Ca}^{2+}-\mathrm{Mg}^{2+}-\mathrm{Cl}^{-}$and $\mathrm{Ca}^{2+}-\mathrm{HCO}_{3}^{-}$ type in the study area. 
Table 5 Water quality index and its quality class for each hydrostation in study area

\begin{tabular}{|c|c|c|c|c|}
\hline Sample No & Hydro-Station & Sample Source & WQI Value & Class \\
\hline S-1 & Near Surha & Key Well & 61.94 & Poor \\
\hline S-2 & Ajnar & Hand Pump & 86.02 & Very Poor \\
\hline S-3 & Panwari & Hand Pump & 115.93 & Unsuitable \\
\hline S-4 & Pasanabad Chauraha & Hand Pump & 4.75 & Excellent \\
\hline S-5 & Ajnar near Electiric House & Hand Pump & 10.56 & Excellent \\
\hline S-6 & Beside Koelari Nadi & Hand Pump & 9.94 & Excellent \\
\hline S-7 & Magariya & Hand Pump & 7.78 & Excellent \\
\hline S-8 & Mahua Panwari & Hand Pump & 8.98 & Excellent \\
\hline S-9 & Towards Rath Road & Hand Pump & 10.35 & Excellent \\
\hline S-10 & Kodai & Hand Pump & 29.58 & Good \\
\hline S-11 & Gagaura Chauki Village & Hand Pump & 13.70 & Excellent \\
\hline S-12 & Leluwahi & Hand Pump & 14.72 & Excellent \\
\hline S-13 & Ruri Kalan & Hand Pump & 13.59 & Excellent \\
\hline S-14 & Raipura Village & Hand Pump & 11.17 & Excellent \\
\hline S-15 & Panwari Village & Hand Pump & 12.79 & Excellent \\
\hline S-16 & Dhwar Village & Hand Pump & 11.55 & Excellent \\
\hline S-17 & On crossing of Bijainagar Sagar & Hand Pump & 12.89 & Excellent \\
\hline S-18 & Bijainagar Sagar & Key Well & 7.10 & Excellent \\
\hline S-19 & Surha & Hand Pump & 10.79 & Excellent \\
\hline S-20 & Makaniya Purva & Hand Pump & 14.85 & Excellent \\
\hline S-21 & Bhatewar Village & Hand Pump & 12.33 & Excellent \\
\hline S-22 & Nakra Village & Hand Pump & 8.52 & Excellent \\
\hline S-23 & Chhakera Village & Hand Pump & 11.30 & Excellent \\
\hline S-24 & Bahadurpura Village & Hand Pump & 9.98 & Excellent \\
\hline S-25 & Mochipura & Hand Pump & 12.23 & Excellent \\
\hline S-26 & Takariya & Hand Pump & 11.16 & Excellent \\
\hline S-27 & Belbai Village & Key Well & 11.29 & Excellent \\
\hline S-28 & Singhanpur Baghari & Hand Pump & 10.85 & Excellent \\
\hline S-29 & Khama & Hand Pump & 115.64 & Unsuitable \\
\hline S-30 & Chauka & Hand Pump & 8.81 & Excellent \\
\hline S-31 & Bihat & Key Well & 9.25 & Excellent \\
\hline S-32 & Seonrhi & Hand Pump & 10.31 & Excellent \\
\hline S-33 & Bhatewra & Hand Pump & 8.56 & Excellent \\
\hline S-34 & Ghosiona & Hand Pump & 13.91 & Excellent \\
\hline S-35 & Nanwara & Hand Pump & 67.64 & Poor \\
\hline S-36 & Mohan Sagar & Key Well & 15.11 & Excellent \\
\hline S-37 & Narerl & Key Well & 16.77 & Excellent \\
\hline S-38 & Lohari & Hand Pump & 8.90 & Excellent \\
\hline S-39 & Jharauli & Hand Pump & 7.72 & Excellent \\
\hline S-40 & Parthanla & Hand Pump & 8.20 & Excellent \\
\hline S-41 & Nauranga & Hand Pump & 88.09 & Very Poor \\
\hline S-42 & Bamrara & Key Well & 8.05 & Excellent \\
\hline S-43 & Padora & Hand Pump & 9.92 & Excellent \\
\hline
\end{tabular}




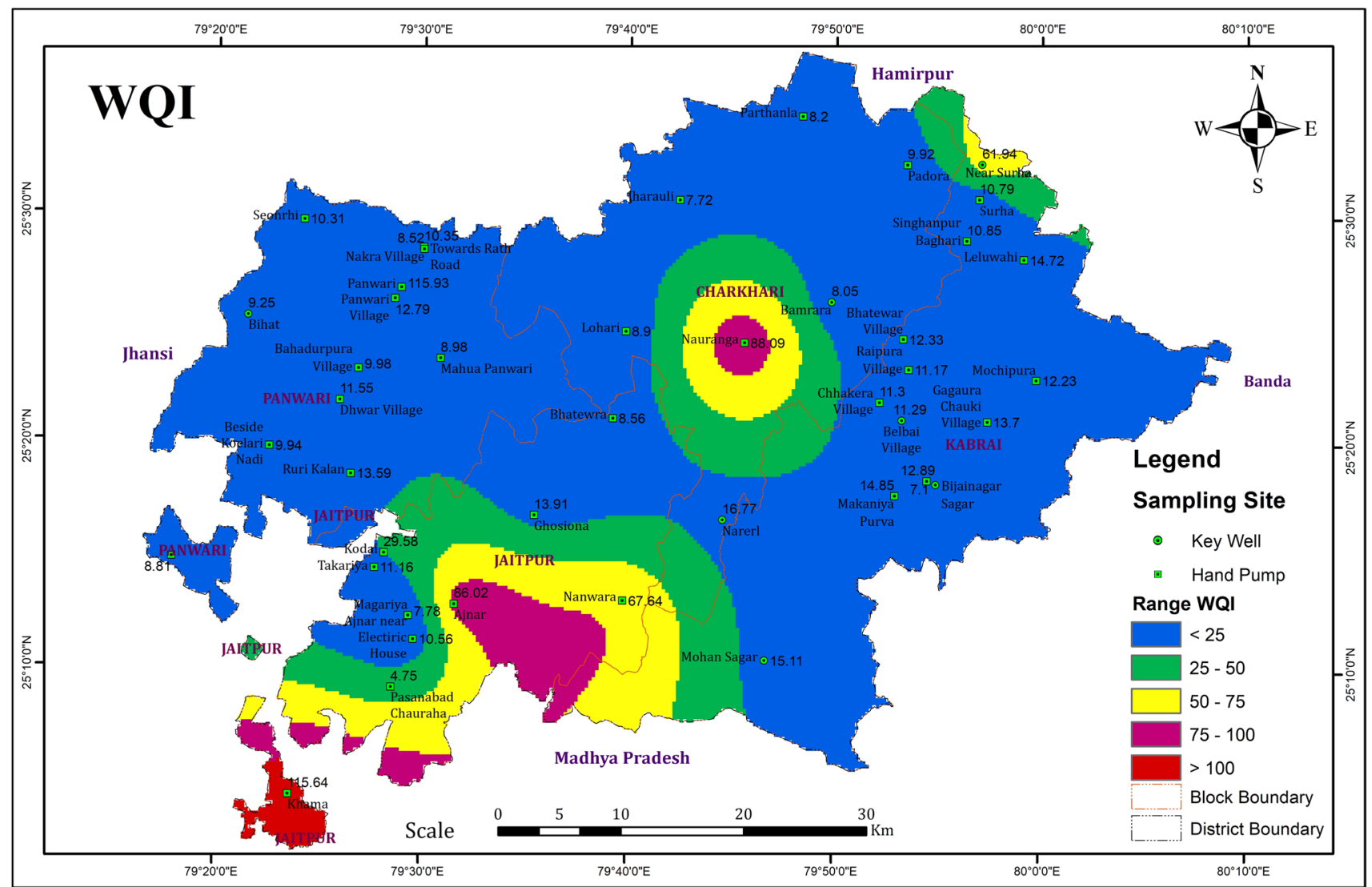

Fig. 3 Water quality index map of the study area, District Mahoba

- The high value of WQI has been found, which is due to the higher values of chloride, fluoride, nitrate, manganese, iron, and nickel in the groundwater, which warrants immediate attention.
- On the basis of WOI, it is concluded that the groundwater is safe and potable in the study area except for localized pockets in Jaitpur and Charkhari Blocks. 
Fig. 4 Types of groundwater

\section{Hill-Piper Trilinear Diagram}

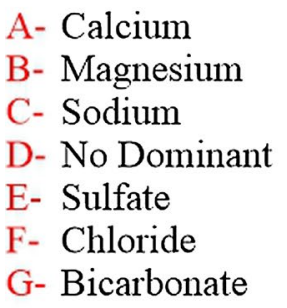

A- Calcium

B- Magnesium

C- Sodium

D- No Dominant

E- Sulfate

G- Bicarbonate

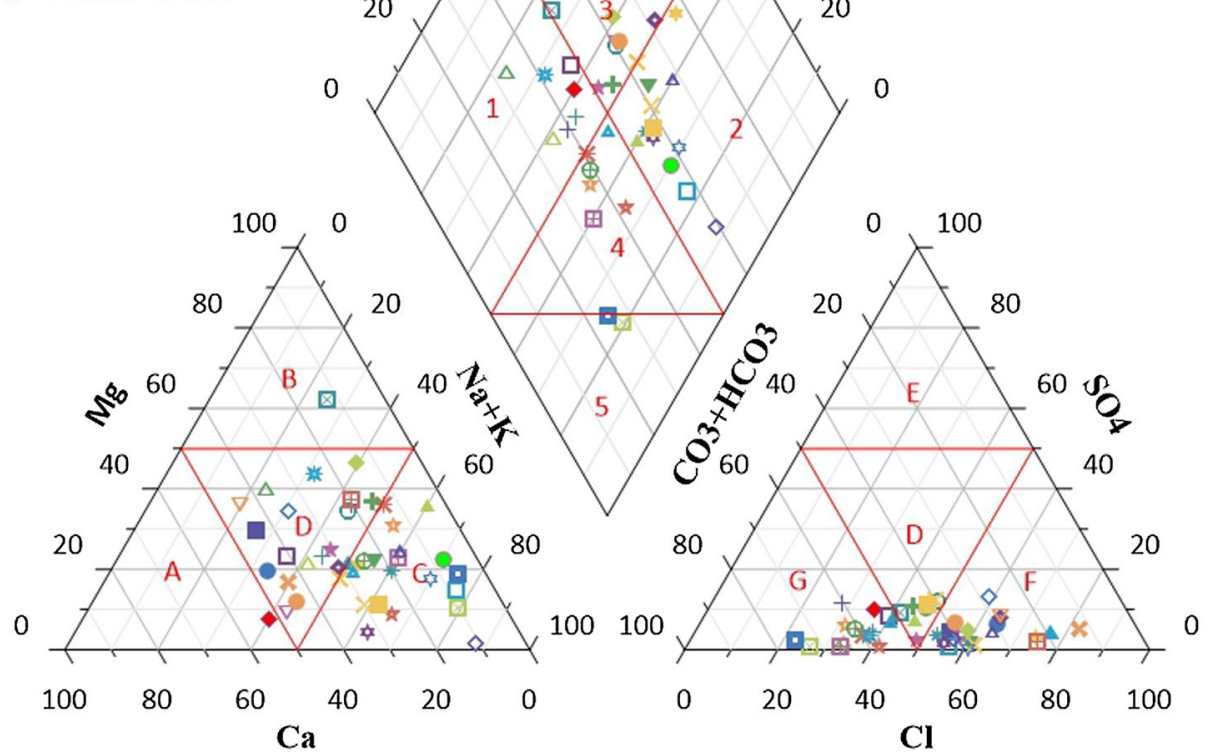

Acknowledgements Our thanks go to Central Groundwater Board (CGWB), Lucknow, NR, Region and Department of Soil Science \& Agricultural Chemistry, Banaras Hindu University, Varanasi for their valuable support during the chemical analysis of groundwater samples.

Funding There is no sponsored/finical assistance is involved in the present research work.

\section{Compliance with ethical standards}

Conflict of interest This is certified that there is no conflict of interest either academic or commercial.

Ethical standards The research work is original in nature and does not contain the others findings accept referred work. Therefore, the entire manuscript follows the Ethical Standards.

Open Access This article is licensed under a Creative Commons Attribution 4.0 International License, which permits use, sharing, adaptation, distribution and reproduction in any medium or format, as long as you give appropriate credit to the original author(s) and the source, provide a link to the Creative Commons licence, and indicate if changes were made. The images or other third party material in this article are included in the article's Creative Commons licence, unless indicated otherwise in a credit line to the material. If material is not included in the article's Creative Commons licence and your intended use is not permitted by statutory regulation or exceeds the permitted use, you will need to obtain permission directly from the copyright holder. To view a copy of this licence, visit http://creativecommons.org/licenses/by/4.0/.

\section{References}

Adams S, Titus R, Pietersen K, Tredoux G, Harris C (2001) Hydrochemical characteristics of aquifers near Sutherland in the Western Karoo, South Africa. J Hydrol 241:91-103

Aghazadeh N, Chitsazan M, Golestan Y (2017) Hydrochemistry and quality assessment of groundwater in the Ardabil area. Iran Appl Water Sci 7:3599-3616

Alobaidy AM, Abid HS, Maulood BK (2010) Application of water quality index for assessment of Dokan lake ecosystem, Kurdistan region, Iraqi. J Water Res Prot 2:792-798

Apambire WB, Boyle DR, Michel FA (1997) Geochemistry, genesis, and health implications of fluoriferous groundwater in the upper regions of Ghana. Environ Geol 33:13-22

APHA, AWWA, WEF (2017) Standard Methods for the Examination of Water and Wastewater. 23th edition., APHA, Washington, DC. v.6.

Aravindan S, Shankar K, Ganesh BP, Rajan KD (2010) Hydrogeochemical mapping of in the hard rock area of Gadilam River basin, using GIS technique. Tamil Nadu Indian J Appl Geochem 12(2):209-216

Balamurugan P, Kumar PS, Shankar K (2020a) Dataset on the suitability of groundwater for drinking and irrigation purposes in 
the Sarabanga River region, Tamil Nadu, India. Data in Brief 29:105255

Balamurugan P, Kumar PS, Shankar K, Nagavinothini R, Vijayasurya K (2020b) Non-carcinogenic risk assessment of groundwater in Southern Part of Salem District in Tamilnadu, India. J Chil Chem Soc 65:4697-4707

Bawoke GT, Anteneh ZL (2020) Spatial assessment and appraisal of groundwater suitability for drinking consumption in Andasa watershed using water quality index (WQI) and GIS techniques: Blue Nile Basin. Northwestern Ethiopia Cogent Eng 7(1):1748950

BIS (Bureau of Indian Standard) (2012) Indian standard drinking water specification, second revision, pp.1-16.

BIS (Bureau of Indian Standard) (2015) Indian standard drinking water specification. second revision, pp.2-6.

Boyd CE (2000) Water Quality an Introduction. Kluwer Acadamic Publi-shers, Boston, USA, p 330

Boyd SR, Hall A, Pillinger CT (1993) The measurement of d15N in crustal rocks by static vacuum mass spectrometry: Application to the origin of the ammonium in the Cornubian batholith, southwest England. Geochim Cosmochim Acta 57:1339-1347

Brhane GK (2018) Characterization of hydro chemistry and groundwater quality evaluation for drinking purpose in Adigrat area, Tigray, northern Ethiopia. Water Sci 32:213-229

Brown RM, Mccleiland NJ, Deiniger RA, O'Connor MF (1972) Water quality index-crossing the physical barrier. Res Jerusalem 6:787-797

Carrillo-Rivera JJ, Cardona A, Edmunds WM (2002) Use of abstraction regime and knowledge of hydrogeological conditions to control high-fluoride concentration in abstracted groundwater: San Luis Potosi basin, Mexico. J Hydrol 261:24-47

Cerar S, Urbanc J (2013) Carbonate chemistry and isotope characteristics of groundwater of Ljubljansko polje and Ljubljansko Barje aquifers in Slovenia. Sci World J 2013:1-11

Chapman D (1996) Water Quality Assessment-A guide to use of biota, sediments and water environmental monitoring 2nd Edition EPFN Spon. London. p.626.

Chatterjee C, Raziuddin M (2002) Determination of Water Quality Index (WQI) of a degraded river in Asansol industrial area (West Bengal). Nat Environ Pollut Technol 1:181-189

Chaurasia AK, Pandey HK, Tiwari SK, Prakash R, Pandey P, Ram A (2018) Groundwater quality assessment using water quality index (WQI) in parts of Varanasi district, Uttar Pradesh, India. J Geol Soc India 92:76-82

Dahlgren RA (1994) Soil acidification and nitrogen saturation from weathering of ammonium-bearing rock. Nature 368:838-841

Deshmukh AN, Shah KC, Sriram A (1995) Coal Ash: a source of fluoride pollution, a case study of Koradi thermal power station, District Nagpur. Maharashtra Gondwana Geol Mag 9:21-29

Diersing N, Nancy F (2009) Water quality: Frequently asked questions. Florida Brooks National Marine Sanctuary, Key West, FL

Egereonu UU, Nwachukwu UL (2005) Evaluation of the surface and groundwater resources of Efuru River Catchment, Mbano, South Eastern. Nigeria J Assoc Adv Model Simulat Tech Enterpr 66:53-71

Fantong WY, Satake H, Ayonghe SN, Suh EC, Adelana SM, Fantong EBS, Zhang J (2010) Geochemical provenance and spatial distribution of fluoride in groundwater of Mayo Tsanaga River Basin, Far North Region, Cameroon: implications for incidence of fluorosis and optimal consumption dose. Environ Geochem Health 32:147-163

Gaciri SJ, Davies TC (1993) The occurrence and geochemistry of fluoride in some natural waters of Kenya. J Hydrol 143:395-412

Galloway JN, Dentener FJ, Capone DG, Boyer EW, Howarth RW, Seitzinger SP, Asner GP, Cleveland CC, Green PA, Holland EA, Karl DM (2004) Nitrogen cycles: past, present, and future. Biogeochemistry 70:153-226
Gebrehiwot AB, Tadesse N, Jigar E (2011) Application of water quality index to assess suitablity of groundwater quality for drinking purposes in Hantebet watershed, Tigray, Northern Ethiopia. ISABB J Food Agric Sci 1:22-30

GEMS U (2007) Global drinking water quality index development and sensitivity analysis report. United Nations Environment Programme Global Environment Monitoring System/Water Programme. p.58.

Hei L, Bouchaou L, Tadoumant S, Reichert B (2020) Index-based groundwater vulnerability and water quality assessment in the arid region of Tata city (Morocco). Groundw Sustain Dev:100344

Holloway JM, Dahlgren RA, Hansen B, Casey WH (1998) Contribution of bedrock nitrogen to high nitrate concentrations in stream water. Nature 395:785-788

Horton RK (1965) An index number system for rating water quality. J Water Pollut Control Federation 373:303-306

Jagadeeswari PB, Ramesh K (2012) Deciphering fresh and saline groundwater interface in south Chennai coastal aquifer, Tamil Nadu, India. Int J Res Chem Environ 2:123-132

Jha SK, Nayak AK, Sharma YK (2010) Potential fluoride contamination in the drinking water of Marks Nagar, Unnao district, UP, India. Environ Geochem Health 32:217-226

Johnson DL, Ambrose SH, Bassett TJ, Bowen ML, Crummey DE, Isaacson JS, Winter-Nelson AE (1997) Meanings of environmental terms. J Environ Qual 26:581-589

Kalavathy S, Sharma TR, Suresh KP (2011) Water quality index of river Cauvery in Tiruchirappalli district, Tamilnadu. Arch Environ Sci 5:55-61

Kaminsky LS, Mahoney MC, Leach J, Melius J, Jo Miller M (1990) Fluoride: benefits and risks of exposure. Crit Rev Oral Biol Med 1:261-281

Kangjoo K, Yun ST (2005) Buffering of sodium concentration by cation exchange in the groundwater system of a sandy aquifer. Geochem J 39:273-284

Karro E, Uppin M (2013) The occurrence and hydrochemistry of fluoride and boron in carbonate aquifer system, central and western Estonia. Environ Monit Assess 185:3735-3748

Kavitha MT, Divahar R, Meenambal T, Shankar K, VijaySingh R, Haile TD, Gadafa C (2019a) Dataset on the assessment of water quality of surface water in Kalingarayan Canal for heavy metal pollution, Tamil Nadu. Data in Brief 22:878-884

Kavitha MT, Shankar K, Divahar R, Meenambal T, Saravanan R (2019b) Impact of industrial wastewater disposal on surface water bodies in Kalingarayan canal, Erode district, Tamil Nadu, India. Arch Agric Environ Sci 4(4):379-387

Kavitha R, Elangovan K (2010) Ground water quality characteristics at Erode district, Tamilnadu India. Int J Environ Sci 1:163-175

Kawo NS, Shankar K (2018) Groundwater quality assessment using water quality index and GIS technique in Modjo River Basin, Central Ethiopia. J Afr Earth Sci 147:300-311

Keshavarzi B, Moore F, Esmaeili A, Rastmanesh F (2010) The source of fluoride toxicity in Muteh area, Isfahan. Iran Environ Earth Sci 61:777-786

Khan D, Hagras MA, Iqbal N (2014) Groundwater quality evaluation in Thal Doab of Indus Basin of Pakistan. Int J Modern Eng Res 4:36-47

Kumar SK, Chandrasekar N, Seralathan P, Godson PS, Magesh NS (2012) Hydrogeochemical study of shallow carbonate aquifers, Rameswaram Island, India. Environ Monit Assess 184:4127-4138

Kumar SK, Logeshkumaran A, Magesh NS, Godson PS, Chandrasekar N (2014) Hydro-geochemistry and application of water quality index (WQI) for groundwater quality assessment, Anna Nagar, part of Chennai City, Tamil Nadu, India. Appl Water Sci $5: 335-343$

Magesh NS, Elango L (2019) Spatio-temporal variations of fluoride in the groundwater of Dindigul District, Tamil Nadu, India: a

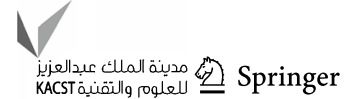


comparative assessment using two interpolation techniques. GIS Geostat Techn Groundwater Sci:283-296.

Magesh NS, Krishnakumar S, Chandrasekar N, Soundranayagam JP (2013) Groundwater quality assessment using WQI and GIS techniques, Dindigul district, Tamil Nadu, India. Arab J Geosci 6:4179-4189

Majumdar D, Gupta N (2000) Nitrate pollution of groundwater and associated human health disorders. Indian J Environ Health 42:28-39

McCray JE, Kirkland SL, Siegrist RL, Thyne GD (2005) Model parameters for simulating fate and transport of on-site wastewater nutrients. Ground Water 43:628-639

Modibo Sidibé A, Lin X, Koné S (2019) Assessing groundwater mineralization process, quality, and isotopic recharge origin in the Sahel Region in Africa. Water 11:789

Mostafa MG, Uddin SMH, Haque ABMH (2017) Assessment of hydrogeochemistry and groundwater quality of Rajshahi City in Bangladesh. Appl Water Sci. 7:4663-4671

Narsimha A, Sudarshan V (2013) Hydrogeochemistry of groundwater in Basara area, Adilabad District, Andhra Pradesh, India. J Appl Geochem 15:224-237

Naseem S, Rafique T, Bashir E, Bhanger MI, Laghari A, Usmani TH (2010) Lithological influences on occurrence of high-fluoride groundwater in Nagar Parkar area, Thar Desert, Pakistan. Chemosphere 78:1313-1321

Ozsvath DL (2006) Fluoride concentrations in a crystalline bedrock aquifer Marathon County, Wisconsin. Environ Geol 50:132-138

Panda RB, Sahu BK, Garnaik BK, Sinha BK, Nayak A (1991) Investigation of water quality of Brahmani River. Indian J Environ Health 33:45-50

Pandey HK, Duggal SK, Jamatia A (2016) Fluoride contamination of groundwater and it's hydrogeological evolution in District Sonbhadra (UP) India. Proc Natl Acad Sci, India, Sect A 86:81-93

Panigrahi T, Das KK, Dey BS, Panda RB (2012) Assessment of Water Quality of river Sono, Balasore. Int J Environ Sci 3:49-56

Panneerselvam B, Paramasivam SK, Karuppannan S et al (2020a) A GIS-based evaluation of hydrochemical characterisation of groundwater in hard rock region, South Tamil Nadu. India Arab J Geosci 13(17):1-22

Panneerselvam, B., Karuppannan, S., \& Muniraj, K. (2020b). Evaluation of drinking and irrigation suitability of groundwater with special emphasizing the health risk posed by nitrate contamination using nitrate pollution index (NPI) and human health risk assessment (HHRA). Human and Ecological Risk Assessment: An Int J, pp 1-25.

Pius A, Jerome C, Sharma N (2012) Evaluation of groundwater quality in and around Peenya industrial area of Bangalore, South India using GIS techniques. Environ Monit Assess 184:4067-4077

Rafique T, Naseem S, Usmani TH, Bashir E, Khan FA, Bhanger MI (2009) Geochemical factors controlling the occurrence of high fluoride groundwater in the Nagar Parkar area, Sindh, Pakistan. J Hazard Mater 171:424-430

Raju NJ, Dey S, Das K (2009) Fluoride contamination in groundwater of Sonbhadra district, Uttar Pradesh, India. Curr Sci 96:979-985

Rao NS (2006) Nitrate pollution and its distribution in the groundwater of Srikakulam district, Andhra Pradesh, India. Environ Geol 51:631-645
Rao NS (2009) Fluoride in groundwater, Varaha River Basin, Visakhapatnam District, Andhra Pradesh, India. Environ Monit Assess 152:47-60

Ravindra K, Garg VK (2007) Hydro-chemical survey of groundwater of Hisar city and assessment of defluoridation methods used in India. Environ Monit Assess 132:33-43

Rivett MO, Russ SR, Morgan P, Smith JW, Bemment N, CD, (2008) Nitrate attenuation in groundwater: a review of biogeochemical controlling processes. Water Res 42:4215-4232

Sadat-Noori SM, Ebrahimi K, Liaghat AM (2014) Groundwater quality assessment using the Water Quality Index and GIS in SavehNobaran aquifer. Iran Environ Earth Sci 71:3827-3843

Sarfo AK, Shankar K (2020) Application of geospatial technologies in the COVID-19 fight of Ghana. Transact Indian Nat Acad Eng 5:193-204

Saxena V, Ahmed S (2003) Inferring the chemical parameters for the dissolution of fluoride in groundwater. Environ Geol 43:731-736

Selvam S, Manimaran G, Sivasubramanian P (2013) Hydrochemical characteristics and GIS-based assessment of groundwater quality in the coastal aquifers of Tuticorin Corporation, Tamilnadu, India. Appl Water Sci 3:145-159

Shankar K, Aravindan S, Rajendran S (2010) GIS based groundwater quality mapping in Paravanar River Sub-Basin, Tamil Nadu, India. Int J Geomat Geosci 1:282-296

Shankar K, Aravindan S, Rajendran S (2011) Hydrogeochemistry of the Paravanar river sub-basin, Cuddalore District, Tamilnadu, India. E-J Chem 8:835-845

Shankar K, Aravindan S, Rajendran S (2011) Spatial distribution of groundwater quality in Paravanar river sub basin, Cuddalore district, Tamil Nadu. Int J Geomat Geosci 1:914-931

Shankar K, Kawo NS (2019) Groundwater quality assessment using geospatial techniques and WQI in North East of Adama Town, Oromia Region. Ethiopia Hydrospatial Anal 3(1):22-36

Soujanya Kamble B, Saxena PR, Kurakalva RM, Shankar K (2020) Evaluation of seasonal and temporal variations of groundwater quality around Jawaharnagar municipal solid waste dumpsite of Hyderabad city. India SN Appl Sci 2:498

Stallard RF, Edmond JM (1983) Geochemistry of the Amazon: 2. The influence of geology and weathering environment on the dissolved load. J Geophys Res: Oceans 88:9671-9688

Tripathy JK, Sahu KC (2005) Seasonal hydrochemistry of groundwater in the Barrier Spit system of the Chilika Lagoon, India. J Environ Hydrol 13:1-9

Venkateswaran S, Karuppannan S, Shankar K (2012) Groundwater quality in Pambar sub-basin, Tamil Nadu, India using GIS. Int J Recent Sci Res 3:782-787

Vikas C, Kushwaha RK, Pandit MK (2009) Hydrochemical status of groundwater in district Ajmer (NW India) with reference to fluoride distribution. J Geol Soc India 73:773-784

WHO (2017) Guideline for drinking water quality, 4th edn. World Health Organization, Geneva

Yisa J, Jimoh T (2010) Analytical studies on water quality index of river Landzu. Am J Appl Sci. 7:453-458

Publisher's Note Springer Nature remains neutral with regard to jurisdictional claims in published maps and institutional affiliations. 